\title{
FUSARIUM WILT OF POTATO IN THE HUDSON
} RIVER VALLEY, NEW YORK

\author{
BY \\ ROYAL J: HASKELL \\ $+1$ \\ A THESIS \\ PRESENTED TO THE FACULTY OF THE GRADUATE SCHOOL \\ OF CORNELL UNIVERSITY FOR THE DEGREE \\ OF. DOCTOR OF PHILOSOPHY
}

Reprinted from Phyтopatholoax, Vol. IX, No. 6 June, 1919 



\title{
FUSARIUM WILT OF POTATO IN THE HUDSON RIVER VALLEY, NEW YORK
}

BY

ROYAL J. HASKELL

\begin{abstract}
A THESIS
PRESENTED TO THE FACULTY OF THE GRADUATE SCHOOL OF CORNELL UNIVERSITY FOR THE DEGREE OF DOCTOR OF PHILOSOPHY
\end{abstract}

Reprinted from Phytopathology, Vol. IX, No. 6 June, 1919 



\title{
FUSARIUM WILT OF POTATO IN THE HUDSON RIVER VALLEY, NEW YORK ${ }^{1}$
}

\author{
R O Y A L J. H A S K E L L
}

\section{With Plates XIII to XV}

During the summer of 1914 a disease of potatoes resembling Fusarium wilt was reported as being serious in various parts of the southern Hudson River Valley, particularly in Dutchess County, N. Y. The effect of this disease on the tops of the plants was the same as that described by Smith and Swingle (14), Manns (6), Orton (9, 10), and others as being due to Fusarium oxysporum. The condition of the affected tubers, however, was somewhat different from that commonly reported for Fusarium wilt. Because of the seriousness and somewhat doubtful identity of the trouble it was deemed advisable to make a closer study of the disease. The following paper gives the results of work during the years of 1915 and 1916, the summers being spent in a field laboratory in Dutchess County, and the winters at the College of Agriculture at Ithaca, N. Y.

\section{The Host}

\section{POTATO PRODUCTION IN THE LOWER HUDSON RIVER VALLEY}

- Potato raising in the southern portion of the Hudson Valley occupies a relatively small place on the average farm. Indeed, so few potatoes are produced that there are not enough to supply the local markets and

1 Also presented to the Faculty of the Graduate School of Cornell University, July, 1917, as a major thesis in partial fulfillment of the requirements for the degree of doctor of philosophy.

The writer wishes to acknowledge the valuable aid of Professor M. F. Barrus under whose supervision this investigation was conducted. Thanks are also due the Dutchess County Farm Bureau Association and Mr. Henry Morgenthau, Jr. for financial assistance in connection with the work. 
importation from outside sources is necessary. This condition has not always existed, however, as fifty or sixty years ago potatoes occupied an important place among the farm crops. The census figures show that in 1839 Dutchess County produced 590,000 bushels and in 1849, 385,941 bushels, while in 1899 and 1909 only 210,437 and 300,275 bushels respectively were reported. This decrease in production is partly due to lower yields and partly to fewer acres being planted. The following figures show the general decrease in number of acres devoted to potatoes in the county during the last forty years; in 1879, 4218 acres, in 1889, 2941 acres, in 1899, 2693 acres, in 1909, 3041 acres. Furthermore it is the opinion of many of the older inhabitants of this section that potatoes do not produce so well as they did fifty years ago. As a result of the lower yield it has gradually been concluded that potatoes are not a profitable crop in Dutchess County and the acreage has slowly fallen off.

Much of the soil, of which there are many types, is well adapted to potato culture but the climate is not favorable to the crop on account of the high summer temperatures which prevail throughout the months of July and August. Potatoes are planted in May or June and as a result they are often at the height of their growth when they encounter hot weather and drought. Under these conditions the vines tip-burn, become subject to Fusarium wilt and die early with a yield which is far below the average per acre of the state. This holds true, not only for Dutchess County, but for the entire southern Hudson River Valley where much the same climatic and soil conditions exist.

With the exception of several fields of twenty to forty acres the individual potato fields in Dutchess County are of small size. The yield is rather light, being as a rule from ten to twenty-five bushels lower than the average for the state. Most of the potatoes planted in this locality are late varieties of both the Green Mountain and Rural groups, although some farmers grow for home use a few early potatoes such as the Early Rose and Irish Cobbler. Much of the seed is obtained through local dealers who buy from Maine or western New York. It is generally considered in Dutchess County that homegrown potatoes do not give good results when planted year after year and as a result we find farmers frequently changing their seed.

Potatoes are commonly planted on sod or after corn and often the same piece of land is used for the crop two or more successive years. Manure and commercial fertilizer are used either separately or together. The crop is cared for mostly by hand, there being little potato machinery used except on some of the larger farms. Spraying with Bordeaux mixture is not generally practiced. 


\section{The Disease}

The potato disease here described is one that has long been known under the name of "Fusarium wilt" or "Fusarium blight." Although the latter designation is more significant of the nature of the malady than is the former, still, the name "Fusarium wilt" is preferred because it is better known and much more widely used. The names given to the disease as it occurrs on the tuber vary according to the nature of the injury. At harvest time affected potatoes most often show the condition variously spoken of as "stem end browning," "internal browning," "vascular browning," or, preferably, "Fusarium browning." Tubers borne on diseased vines sometimes develop a condition similar to what has been called "net-necrosis." The name "Fusarium necrosis" is suggested for this type of trouble. Such names as "Fusarium rot," "dry rot" and "stem end rot" have been used to designate extreme or late stages of the disease on this part of the host.

It is not necessary in this paper to review the history of the investigation of this disease. The works of Smith and Swingle (14), Orton $(9,10)$, Manns (6), Carpenter (2), Link (5), and others are too well known to need summarizing. It is interesting to note however that the first description of Fusarium wilt of the potato vine itself was given in 1895 by Prof. F. C. Stewart (15), who studied the disease on Long Island, $\mathrm{N}$. Y., and also in the same portion of the state that was later under observation by the writer, the lower Hudson River Valley. Stewart does not mention the cause of the disease with certainty, but his description is so complete and accurate for Fusarium wilt as it has since been diagnosed by others, and as it has been noted in that region by the writer, that there is but little doubt that this was the disease concerned. In 1897 Stewart (16) again called attention to this "stem-blight"in New York and stated that it continued to be destructive in 1896 and 1897.

\section{GEOGRAPHIC RANGE}

Fusarium wilt appears to be a distinctly American disease. Orton observed no typical cases during the course of a study trip through England, Germany, and Austria in 1911, Wollenweber (18) finds the Fusarium oxysporum of Smith and Swingle to be different from a European form, and Sherbakoff (13) speaks of the fungus as possibly occurring in Europe and Africa but he presents no proof that this is the case. Within the United States Fusarium wilt occurs widely. It has been reported from practically every state in the Union with the exception of parts of northern New England and even in this section it is probable that a careful search would reveal its presence, at least in small amounts. The 
disease seems to be most abundant along the southern border of the late potato area and becomes less frequent as one proceeds northward. Heavy losses have been reported from many states, particularly from parts of New York, New Jersey, Pennsylvania, Ohio, Michigan, Indiana, Illinois, Missouri, South Dakota, Nebraska, Colorado, Utah, New Mexico and California.

The disease has been observed by the writer in various parts of the state of New York. It has been seen most abundantly in the southeastern portion, particularly in the counties of Dutchess, Orange, Putnam and Westchester, and on Long Island. In some seasons, however, it is very common in parts of western New York, especially Onondaga, Ontario, Oswego and Steuben Counties. Mild cases of the disease may be seen almost any year in the southern and western parts of the state. It is only when weather conditions are especially favorable that it is severe. The writer has not observed Fusarium wilt in the northern portion of the state. If it occurs there it is not of consequence.

\section{ECONOMIC IMPORTANCE}

\section{General considerations}

In the greater portion of New York Fusarium wilt is not a serious trouble, but in the southern Hudson River Valley, where conditions are favorable, it appears to be the limiting factor in potato production. In this region it is not uncommon to see fields with half of the plants dying from wilt at a time when the tubers are only half grown. The amount of disease varies widely on individual farms. Some fields of large size have been observed where it was impossible to find an entirely healthy plant while other fields exhibited only a few affected individuals. With a few exceptions, the writer did not see a field in Dutchess County, among the large number that he visited in 1915 and 1916, where he could not find the disease.

In the spring of 1915 potatoes of the 1914 crop were examined in the cellars on thirty Dutchess County farms. Thirty-one per cent of these stored potatoes were found to be affected. The greatest amount of disease in any one lot of potatoes was 100 per cent and the smallest amount 3 per cent. Tubers on all of the farms showed some of the disease and all but three of them had more than 10 per cent.

\section{Nature of the losses}

The losses resulting from the disease are of several sorts.

1. The disease may cause an early death of the plant with the result that the potatoes do not attain their full size. This loss is a heavy one 
when plants are affected early in the season, but if the disease is late in developing, the loss in this way is not so great. In an effort to get an idea of the amount of reduction in yield that may be brought about by the disease, wilted and healthy hills were dug and weighed in three different fields of late potatoes of the Rural New Yorker type. It was found that the total yield of marketable tubers from diseased hills was less than one-fourth that which was obtained from healthy hills (table 1).

2. The stem end browning in the potatoes makes them less marketable. Since affected tubers outwardly appear sound it often happens that customers unwittingly purchase diseased potatoes. This results in dissatisfaction on the part of the buyer.

3. The cooking quality of the potato is sometimes impaired by the disease. When badly affected tubers are boiled or baked they become discolored and are likely to be water-soaked and soggy.

TABLE 1

A comparison of yields of potatoes from healthy vines and from those affected with Fusarium wilt, Dutchess County, September, 1916

\begin{tabular}{|c|c|c|c|c|c|c|}
\hline \multirow{2}{*}{ VARIETY } & \multicolumn{2}{|c|}{$\begin{array}{l}\text { TOTAL WEIGHT OF } \\
\text { TTBERS IN TEN HILLS }\end{array}$} & \multicolumn{2}{|c|}{$\begin{array}{c}\text { WEIGHT OF } \\
\text { MARKETABLE TUBERS }\end{array}$} & \multicolumn{2}{|c|}{ WEIGHT OF CULLS } \\
\hline & Diseased & Healtby & Diseased & Healthy & Diseased & Healthy \\
\hline & pounds & pounds & pounds & pounds & pounds & pounds \\
\hline Rural New Yorker. . & 6 & 12 & 3 & 11 & 3 & 1 \\
\hline Sir Walter Raleigh... & 2 & 9 & 1 & $8 \frac{1}{4}$ & 1 & $\frac{3}{4}$ \\
\hline No. $9 \ldots \ldots$. & $3 \frac{1}{4}$ & 9 & 2 & $7 \frac{1}{2}$ & $1 \frac{1}{4}$ & $1 \frac{1}{2}$ \\
\hline Total. & $11 \frac{1}{4}$ & 30 & 6 & $26 \frac{3}{4}$ & $5 \frac{1}{4}$ & $3 \frac{1}{4}$ \\
\hline
\end{tabular}

4. Waste in paring away the affected portion sometimes represents a considerable loss.

5. Diseased potatoes are unfit for seed purposes. Plants coming from affected seed pieces although not necessarily showing signs of wilt, are not so vigorous as those arising from healthy seed and the yield is not so large (table 3 and plate XIV).

Estimates of the monetary losses from Fusarium wilt are very unsatisfactory. In 1914 F. H. Lacy, farm bureau manager of Dutchess County estimated the loss to be $\$ 50$ per farm or $\$ 200,000$ for the county. In 1915 the writer observed well fertilized fields of late potatoes yielding at the rate of 88 bushels per acre when at least 150 bushels should have been expected. A reduction in yield of 50 bushels to the acre is believed to be a very conservative estimate for the loss brought about by Fusarium wilt in Dutchess County during, that season. This would be equivalent to $\$ 150,000$ when the market price is $\$ 1$ per bushel as it was that year. 
The symptoms of Fusarium wilt as observed in Dutchess County agree fairly well with those given by other writers but certain manifestations have been observed in this locality that are omitted or only lightly treated in other descriptions. Because of this, and in order that there may be a clear understanding as to the disease concerned, it is thought well to describe the trouble here in some detail.

\section{On the vine}

The first visible sign of the disease on that part of the potato plant above ground is the appearance of a light green color of the foliage. As the disease develops the plant takes on a yellowish cast, while accompanying the discoloration there is a rolling, wilting, and dying of the leaves beginning at the base and progressing upward. The upper and smaller leave often remain alive for some time after the lower ones are dead, (plates XIII, fig. A and plate XIV, fig. A).

In the southeastern part of New York Fusarium wilt is usually not evident on late potatoes until about the first of August. Scattered individual plants are usually affected first, but in many badly infested soils practically every plant may appear to be in an incipient stage of disease at about the time when the blight first begins to appear. When one looks at such a field from a distance a distinct mottling of light and dark green foliage is noticeable, the light green areas indicating regions in the field where the disease has made greater progress.

\section{On the stem and roots}

Fusarium wilt as it occurs in Dutchess County is primarily a root and stem rot. When diseased plants are removed from the soil carefully and the underground parts washed in water the absence of many of the finer rootlets is very noticeable. Not only have these feeding roots been rotted off but all of the roots are more or less affected as indicated by a dark or brownish color contrasted with ivory white roots of healthy plants. Rhizomes are often attacked from the outside and sometimes rotted through. Lesions commonly occur on the main stem below ground.

As a result of the decay of the root system affected vines fall over and offer very little resistance when pulled. Sometimes deep lesions develop on the stem near the surface of the ground and in this case aerial tubers may be formed in the axils of the leaves much as in the case of plants affected with Rhizoctonia (plate XIV, fig. C). If there is an abun- 
dant supply of soil moisture the small, topmost leaves of affected plants may remain alive for some time, being supplied with water by the few diseased or healthy roots that remain. In this case the life processes of the plant are maintained at a low ebb and are carried on by organs and tissues that are wholly or partially diseased. It is believed that this fact has an important bearing on the condition of the tubers that are produced on wilted plants.

When the stalks are entirely dead a pink or purple coloration is often evident on some of the dead subterranean parts. This color is not unlike that produced by Fusarium oxysporum Schlecht, on certain artificial media.

\section{On the tubers}

The potatoes that are borne on diseased vines are usually affected with an internal, vascular discoloration. The character of this affection varies from a slight yellowing or browning at the point of attachment of the rhizome to an intense darkening of the vascular elements onehalf to two-thirds of the way through the potato. All gradations are found between these two extremes. This necrosis of the conductive tissues is very often not confined to the fibrovascular ring alone but includes many of the smaller vessels that ramify the cortex and medullary tissue from both sides of the vascular ring. When potatoes badly affected in this way are cut across the stem end the flesh appears peppered with dark brown streaks surrounded by narrow zones of watersoaked tissue, a condition closely resembling what has been called "net-necrosis" (plate XV, figs. A and C). When successive slices are taken the brown streaks are still seen occupying the ring of fibro-vascular bundles and penetrating the flesh of the tuber, chiefly the outer medullary tissue. As the cuts are made deeper the discoloration is found to be less intense, finally changing to a yellow and somewhat water-soaked condition, and is more and more confined to the vascular ring. The extreme limits of discoloration are in this latter tissue, and, in severe cases; extend nearly to the distal or "bud" end of the tuber. Usually however there is not much evidence of disease in this half of the potato.

When a tuber, affected with Fusarium necrosis, as described above, is pared rather deeply, so that the vascular ring is laid bare, the brown streaks in this tissue appear somewhat like a network radiating out from the stem as a center and enveloping a greater or lesser portion of the potato.

Other writers on Fusarium wilt of potatoes have noted similar conditions to those just mentioned. Smith and Swingle (14:18) reported a brown specking of the flesh particularly in the region of the vascular 
ring and most noticeable at the stem end; and Manns (6:308) shows a photograph illustrating the trouble.

Affected potatoes appear sound externally. However, there are sometimes apparent from the outside slight indications that aid in diagnosis. The rhizome often adheres firmly to the tuber. This may be on account of its being rotted off between the stalk and the potato or because of cessation of growth before normal abscission has taken place. Again a dark color may be evident on the tuber around the point of attachment of the underground stem. This is due to the blackened vascular bundles showing through the thin skin and cortex. A slight, sunken, dry rot is sometimes developed at this point but this is usually much more apparent on stored than on new potatoes (plate XV, fig. D).

Under humid conditions and high temperatures in the spring, old tubers may become entirely rotted, in which case, the flesh becomes soft rotted, blackish in color, and emits a characteristic and not unpleasant odor. Under moisture and temperature conditions unfavorable for rot the decay is of a dryer nature and progresses very slowly if at all. In the cool, dry cellars of Dutchess County comparatively little of this storage rot develops although it is frequently observed.

The production of spindling sprouts by affected tubers. It often happens in this section that when potatoes affected with vascular browning are taken out of storage in the spring they are found to be firmer and less shriveled than healthy tubers in the same lot. This is because they do not produce strong sprouts. Tubers badly affected with Fusarium necrosis usually send forth spindling sprouts, often so small as to resemble mere threads, and moderately or only slightly diseased potatoes show the same tendency, only to a lesser degree (plate XIV, fig. B). The depth to which the internal vascular browning extends into the tuber is correlated with the production of spindling sprouts by the weakened buds. This is a circumstance to be expected since the vascular system and the buds are in direct connection. The basal "eyes" are most constantly weakened while the strength of those toward the apical end depends on the extent to which the vascular tissue is affected in that portion of the tuber. From the results of planting trials, to be mentioned later, it is evident that the vigor and yield of plants from potatoes that thus produce weak sprouts is much less than from tubers that show strong germination.

\section{ETIOLOGY}

\section{Identity of the fungus}

The fungus associated with wilted vines and diseased tubers in New York appears to be identical macroseopically and microscopically with Fusarium oxysporum Schlecht, as described by Wollenweber (18:28) 
and by Sherbakoff (13:220). A culture of Fusarium oxysporum which had been determined first by Wollenweber and later by Sherbakoff was obtained and compared with the one consistently isolated by the writer from potato plants in Dutchess County, New York. In test tubes the two cultures appeared to be alike in every respect and when grown side by side in the same petri dish, where they had exactly the same conditions for growth, the mycelium of the two was identical, the colonies grew at an equal rate, and the same shade of coloration of the substratum resulted. The writer did not attempt to make a detailed study of Fusarium oxysporum except to establish its identity.

\section{Temperature relations of Fusarium oxysporum}

The relation of temperature to growth of the fungus has an important bearing on the occurrence of the disease. Smith and Swingle (14:49) found the maximum temperature for growth to be about $37.5^{\circ} \mathrm{C}$., the optimum 15 to $30^{\circ} \mathrm{C}$, and the minimum $5^{\circ} \mathrm{C}$. Link $(5: 26)$ gives $38^{\circ}$ to $40^{\circ} \mathrm{C}$., as the maximum, and about $30^{\circ} \mathrm{C}$. for the optimum. The writer grew the fungus in synthetic liquid media in flasks incubated at various temperatures for periods of seven days each. Determinations of the dry weights of the fungus showed the maximum temperature for growth to be about $40^{\circ} \mathrm{C}$. and the optimum 26 to $32^{\circ} \mathrm{C}$. Cultures of Verticillium albo-atrum and Fusarium eumartii grown at the same time and under the same conditions reached their maximum limit for growth at $32^{\circ} \mathrm{C}$., and $36^{\circ} \mathrm{C}$, respectively. It will be seen that Fusarium oxysporum grows best at comparatively high temperatures and that it is able to withstand an unusual amount of heat.

\section{Pathogenicity}

Although it has long been conceded that Fusarium oxysporum Schlecht, is the true cause of Fusarium wilt, it is only recently that sufficient proof of this has been furnished and even now the proof is rather inadequate.

Smith and Swingle (14) showed that the organism was constantly present in the vascular tissues of affected plants but they did not make any inoculations to demonstrate the pathogenicity of the fungus. Manns (6) made inoculations and secured infections but apparently he did not use pure cultures. A number of other workers have secured only negative or inconclusive results. Link (5) was the first to publish results of successful infection experiments in which pure cultures and sterilized soil were used. He does not mention reisolation of $F u$ sarium oxysporum but there is no doubt that it was the pathogene. It 
should be noted however that Link did not have uniform success in bringing about infection. Sometimes he secured 100 per cent diseased plants and at other times, particularly later in the season, few or no in- fections resulted.

It is now known that Fusarium oxysporum causes a rot of the potato tuber under the proper conditions. This was the belief of the earlier workers but the proof was not forthcoming until Carpenter (2:191) and Link (5:10-12) working independently, at about the same time and with different strains of the fungus, demonstrated that the fungus was capable of producing a rot of mature tubers.

Isolations. In the course of the present investigation isolations were made from all parts of affected plants. They were made from the tubers by first disinfecting the specimens in corrosive sublimate, 1-1000 for ten minutes and then cutting them through a small part of the way with a flamed scalpel and breaking them open the remainder of the way. Bits of necrotic tissue were then removed from the locality desired and planted in petri dishes containing potato agar. Stems from which isolations were to be made were first washed free of soil and then disinfected by soaking ten minutes in corrosive sublimate 1-1000. They were then split open lengthwise and the diseased portions removed with a sterilized scalpel. The roots and rhizomes were disinfected by wiping them, after they were washed, with a cloth wet with corrosive sublimate. Sometimes the cortex was stripped off in the process. They were then rinsed in sterilized water and cut into pieces for planting in agar.

The accompanying table giving records of some of the isolations shows the constancy of association of parasite and host, and in what parts of the plant the fungus is most abundant. In making these isolations plantings of diseased tissue were made in plates of potato agar, slightly acidified with lactic acid and containing 2 to 5 per cent glucose.

As is indicated in the first part of table 2 the organism does not commonly occur in the affected tissue inside of potato tubers affected with Fusarium necrosis. No growth results when disinfected potatoes that show the netted and streaked condition are broken open and plantings of diseased tissue from the interior made in media in which Fusarium oxysporum is known to grow well. In other words, the diseased tissue in the interior of tubers affected with Fusarium necrosis is sterile. The writer arrived at this conclusion after making repeated isolation trials and examining a large number of sections under the miscrocope. Smith and Swingle (14:18-19) found the same thing to be true. They were able to find neither fungi nor bacteria in the brown, specked tissue in the interior of affected tubers and were uncertain of the relation of this condition to the Fusarium disease. 
As is further indicated in table 2, the fungus is usually present in the extreme stem-end of affected tubers. The invasion of the tissue is ordinarily 'shallow, however, as cultures readily reveal. Indeed penetration of the corrosive sublimate disinfecting solution into the stem of the potato was often sufficient to kill what little of the fungus there was residing there. Fusarium oxysporum is most easily obtained from those tubers that show a slight sunken dry-rot at the stem-end. Often potatoes are found where there is a decided blackening of the vascular bundles near the stem end, in which case the Fusarium commonly occurs in the blackened tissue.

The fungus is most abundant in the roots, rhizomes, and that part of the stem below ground. It will be seen in table 2 that not as many isolations were secured from the parts of the stem at ground level as below ground level, and when parts of the stem still higher up are tested the fungus is found to be even more rare. The percentages of growth recorded in the table for plantings from rhizomes and roots are somewhat deceptive. The difficulty of getting pure growth of the fungus was encountered and the disinfection was in some cases necessarily rather severe. These two facts, particularly the latter, led to a small percentage of colonies. With more suitable technique it is probable that a much greater percentage of Fusarium growth could be secured.

Inoculations. The constant association of Fusarium oxysporum with affected potato plants is in itself good evidence that the fungus is the cause of this vine and tuber disease as it occurs in southeastern New York. In order to throw more light on the question attempts were made to bring about infection by the use of pure cultures.

In the season of 1915 Green Mountain potato plants growing in a Dutchess County field that had been in sod for seventeen years were inoculated with a pure culture of the fungus. The inoculum was applied below the ground level to wounded and to unwounded stems of various ages. About the second week in August some of the plants began to show signs of disease but so did many other plants in the 20 acre field. Within two weeks practically every plant in the field was affected and observations showed the disease to be general in the entire section. Under these conditions the infection trials were rendered worthless as all the plants had become naturally diseased.

In January, 1915, disinfected tubers of the Irish Cobbler variety were planted in the greenhouse in three plots. of sterilized soil. In plot 1 the soil was inoculated at once with a flask culture of Fusarium oxysporum growing in a liquid synthetic medium. The soil in plot 2 was inoculated later in the same way at a time when the plants were 6 inches high. Plot 3 was left as a check, the soil being uninoculated. About the first 


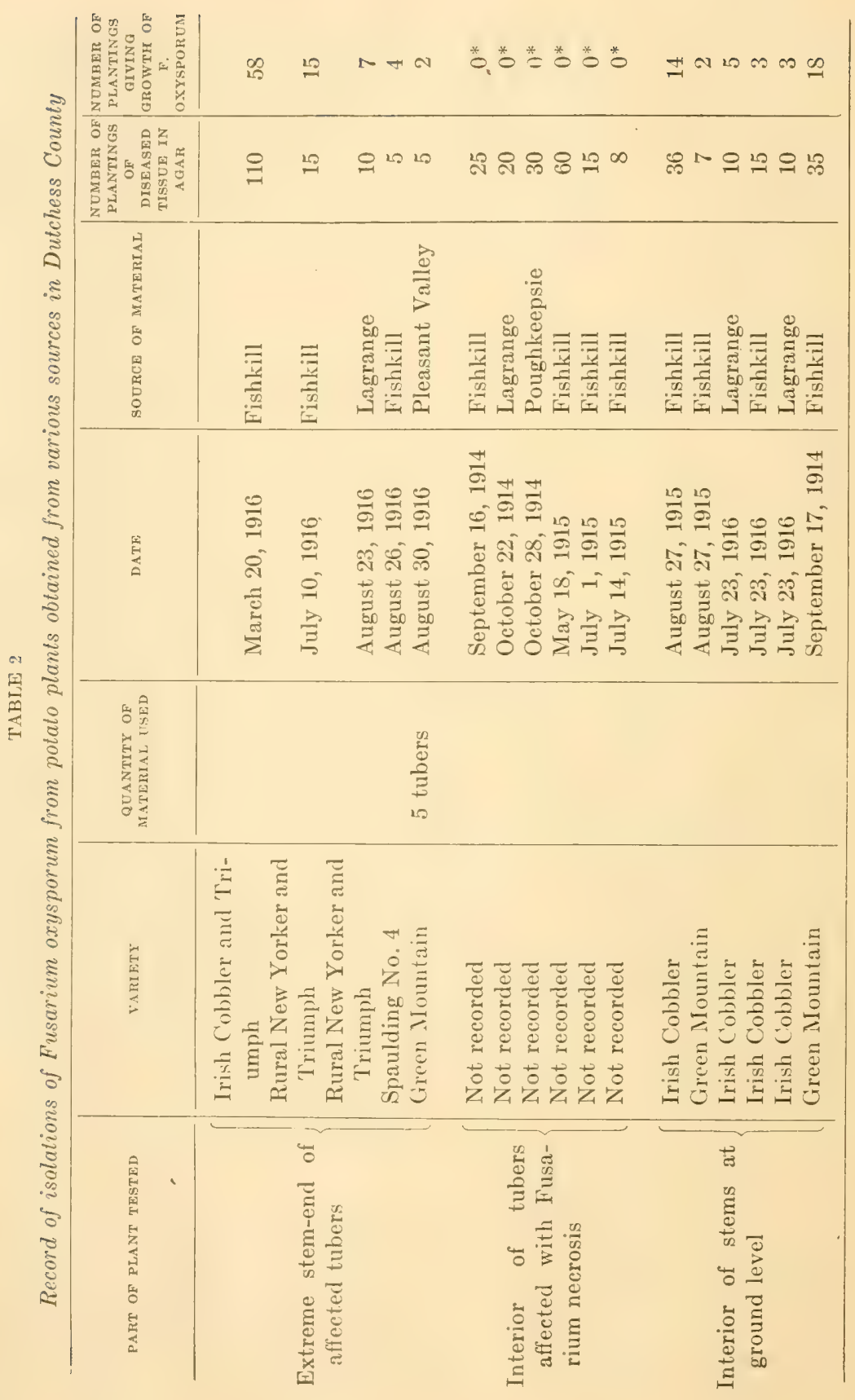




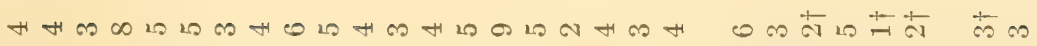
I2

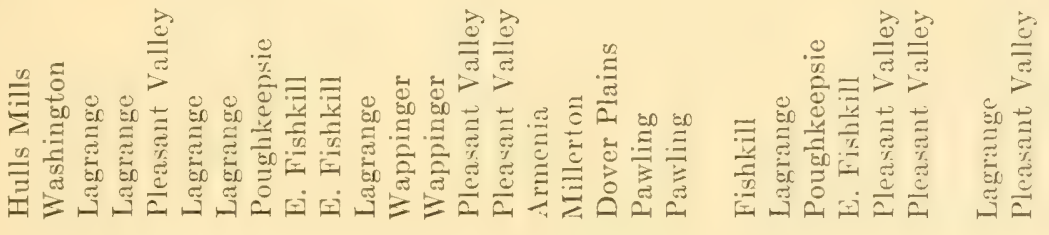

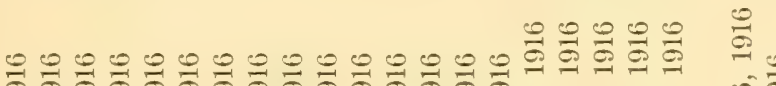

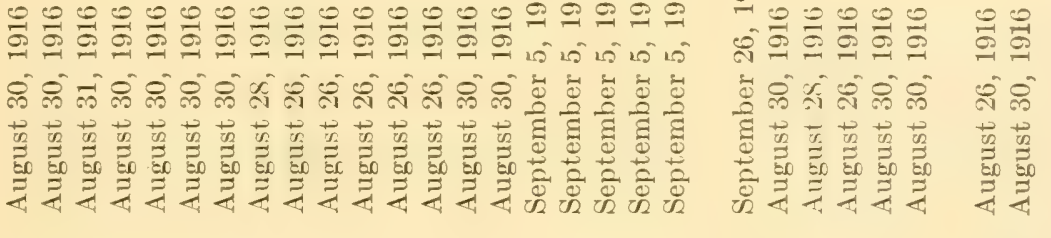

苍苍

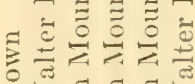

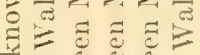

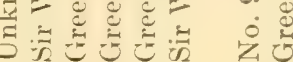

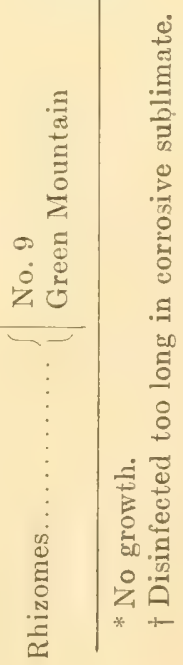


week in April some of the plants in all three plots began to yellow and die. There was no pronounced wilt or rolling of the leaves. When pulled up and examined some of the plants in plot 1 showed a slight browning of the vascular system at the base of the stem. On April 22 plantings of diseased tissue were made in agar plates from two plants of plot 1 that were affected the worst and the following percentages of cultures of Fusarium oxysporum were obtained; plant 1, stem 100 per cent, roots 100 per cent; plant 2, stem 80 per cent, root 0 . No isolations were made from plants in other plots but it is suspected that the organism found its way to the check plot 3 , as the condition of the plants in this plot was the same as those in plot 2. None of the tubers in these two plots were diseased but the vines appeared slightly so.

The temperature of the greenhouse during the experiment just mentioned was kept at $18^{\circ}-21^{\circ} \mathrm{C}$. $\left(65^{\circ}-70^{\circ} \mathrm{F}\right.$.) in the day and $13^{\circ}-15.5^{\circ} \mathrm{C}$. $\left(55^{\circ}-60^{\circ} \mathrm{F}\right.$.) at night. It was thought that this might be too cool to be favorable for infection.

With this in mind more disinfected potatoes were planted in the same inoculated soil and a second crop was grown in the greenhouse during the summer when the temperature in the house was higher. The potatoes were planted May 4 and the crop was dug and examined October 1. Many of the new tubers showed marked stem end browning although none of them appeared to be affected with typical Fusarium necrosis. The fungus was reisolated from affected tubers and found to be the same as the original. The reason for success in this case and not in the other attempt, where the same soil was used, is attributed to the fact that a higher temperature was attained. It was noticed that the plants died first on the side of the plot toward the steam radiator pipe. It appeared that high soil temperatures were favorable and probably necessary for typical infection.

Accordingly in the spring of 1917 an apparatus for regulating soil temperature was employed. Plants were grown in the greenhouse in glazed, earthenware crocks $27 \mathrm{~cm}$. both in diameter and in depth. The crocks of sterilized soil were placed in a water-bath the temperature of which was under thermostatic control. The water-bath was held at a temperature of $36^{\circ} \mathrm{C}$. $\left(97^{\circ} \mathrm{F}\right.$.) for a period of two months. Through the courtesy of Dr. H. A. Edson a culture of Fusarium oxysporum, strain 3395, was obtained from the collection at the Bureau of Plant Industry at Washington. This fungus was used to inoculate the soil in four of six crocks. A flask culture of the organism was mixed with 2 liters of sterilized water and was then poured on the soil immediately after the seed pieces were planted. The two uninoculated crocks served as checks. From the outset the plants growing in the inoculated soil were 
not so vigorous as the checks. They were slower in growing, and the leaves were smaller. Some of the lower leaves died and dropped off but in their place small new shoots developed. All new growth was very slender and spindling.

The reason for this condition was evident when the plants were removed from the soil at the end of six weeks of growth. The young potatoes were just beginning to be formed. It was found that the whole root system was reduced and diseased, and on some of the stems there were lesions at the base and near the point of attachment to the old seed piece. The xylem tissue in the diseased stems was affected for some distance up the stem but not in that part which was above ground. Although the tops of the diseased plants did not resemble those that are affected with Fusarium wilt as it appears in the field, the affected root system and the lesions on the outside and within the stem were exactly like those that occur in the field. Some of the diseased roots were washed, dipped in alcohol and then in sterilized water, cut into small pieces, and planted in agar. Within a few days a number of the roots gave rise to a growth of Fusarium oxysporum which appeared to be exactly like the original strain 3395 .

This experiment was immediately repeated. Disinfected potatoes were planted in sterilized soil in crocks, 25 by $25 \mathrm{~cm}$., that were kept in the water-bath at 'a temperature of $36^{\circ}-39^{\circ} \mathrm{C}$. $\left(97^{\circ}-103^{\circ} \mathrm{F}\right.$.). On March 5 , when the plants were first coming through the ground they were inoculated by pouring dilute liquid cultures of Fusarium oxysporum on the soil. The plants grew remarkably well but with varying degrees of vigor. When the vines were removed June 7 and examined it was found that the high soil temperature had prevented the roots from going deep into the pots. The root systems of inoculated plants were smaller than those of the checks, and the stalks were more slender on that account. An examination of the xylem of inoculated plants showed it to be badly discolored in most of the stems. In some instances the checks also showed this condition but not so badly. Isolations showed that the fungus had spread to the check crocks. The general superiority of the checks nevertheless showed that infection had been secured. Controls grown at greenhouse temperature $\left(55^{\circ}-70^{\circ} \mathrm{F}\right.$.), outside the bath, showed no infection and the root systems penetrated all through the soil in the crocks. Reisolations were made from the inside of the stems of four inoculated plants and 100 per cent growth of Fusarium. resulterd 
The seed. Fusarium oxysporum is undoubtedly disseminated by means of the seed tuber. When affected potatoes are planted the plants arising therefrom may be diseased provided the proper conditions exist. Manns (6:324-328) reports experiments that show the fungus to be transmitted in this way and the writer has seen instances where this was the case. On the other hand $: 2$ often happens that affected seed gives rise to a comparatively healthy crop. In 1897 Prof. F. C. Stewart reported a planting experiment that showed this. He obtained badly diseased potatoes from southeastern New York and planted them on land that had not borne potatoes for at least ten years. Each seed-piece showed some of the disease. Nearly every piece grew but many of the plants were slow in coming up and were weak. It was late in July before any of the plants showed the disease and then only a few of them became mildly affected. From this test Stewart concluded that the causal factor was not communicated to any appreciable extent through the seed but that the use of diseased seed was inadvisable because of low yields.

The writer has carried on planting tests during two years and has had results somewhat comparable with those of Stewart. On November 2, 1914, twelve potatoes affected with Fusarium necrosis and four healthy ones of the same variety, all from Dutchess County, were planted in a plot of disinfected soil in the greenhouse at Ithaca. The plants were slow in growing, partly on account of being grown in the winter, and were weak. Those from the diseased seed were not such vigorous growers as those from the healthy seed and in the end they died somewhat earlier. The plants were removed from the soil and examined April 3 at which time it was found that all of the new tubers were free from disease except one from one of the affected parent tubers that showed a very shallow stem end browning. None of the stalks showed any sign of disease when split open. The plants from the four healthy seed pieces were unaffected also.

In the spring and summer of 1915 planting trials were made in Dutchess County that throw further light on the question of fungus transmission. Five plots were laid out in different parts of the county on land that had not grown potatoes for a number of years. The seed used in each case was carefully sorted into two lots, those tubers that showed distinct stem end browning being considered diseased, and those that showed no affection at the stem end being classed as healthy. The two lots of potatoes were planted side by side, cared for alike, and the results compared. The accompanying table shows the outcome of the tests. 
An examination of the figures shows that the yield from the healthy seed was better than that from the diseased but the percentage of new potatoes affected was about the same in either case. The large amount of disease in the plants from healthy seed was unexpected. It is impossible that the seed was the source of the inoculum. Infection must have taken place from the soil. Since both lots of potatoes were about equally diseased it is reasonable to conclude that not much of the organism could have been transmitted by way of the parent tuber.

Further tests in which diseased Dutchess County seed was planted at Ithaca, New York, show that although the fungus may be communicated through the seed, yet apparently healthy plants may be secured

TABLE 3

Results from planting diseased and healthy potato seed on supposedly clean land in various parts of Dutchess County, 1915

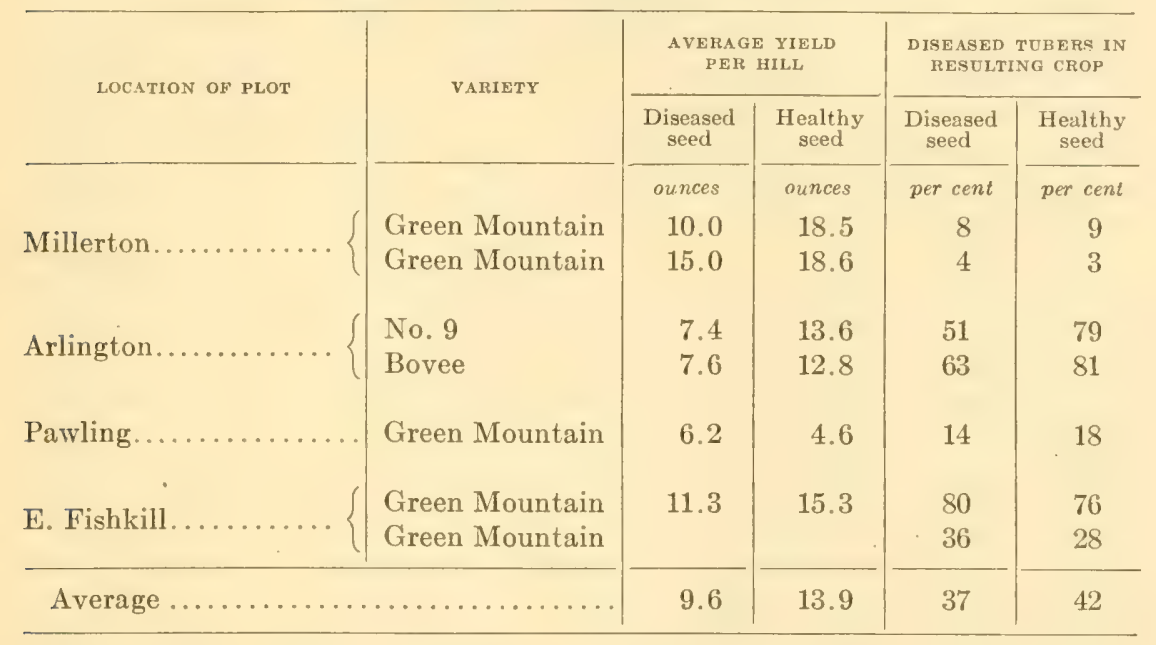

from affected tubers. On May 16, 1915, Dutchess County potatoes with stem end browning were planted in the disease garden of the Department of Plant Pathology at Ithaca. The larger tubers were split lengthwise and the smaller ones planted whole. Stalks came up from all the hills planted but many of them appeared weak, the stems being small in diameter and of a spindling character. After the roots had become well established, however, these weaker plants made better progress and at the end of the season some of them had made a good growth and produced a fair yield, although not so satisfactorily as the vines that were vigorous from the start. The potatoes were dug September 25 and only one hill showed Fusarium necrosis. This hill showed the disease in all its ten tubers, of which six were marketable. The tubers 
from this hill were kept and planted June 9 of the following season. Some of the resulting vines were weak while others gave a fair growth. Toward the middle of August they looked rather poorly. When dug two hills out of seven had no tubers while potatoes from two of the five remaining hills showed a little stem end browning.

In June of the same year (1916) at Ithaca nineteen hills were planted with affected seed from Dutchess County. When dug in the fall the potatoes in seven out of sixteen hills were affected, those in two hills being distinctly diseased, and those in the other five only slightly so.

These planting experiments bear out the author's conclusion regarding the nature of the disease. They show that the causal factor may be communicated to some extent at least through the seed tubers. On the other hand diseased seed often gives rise to plants that produce a healthy crop. This may be either because those tubers do not harbor the pathogene or because it is present but conditions are unfavorable for sufficient development. Both of these reasons are quite possible. The trials further emphasize the fact that affected potatoes are very likely to produce weak and spindling plants with a resulting lowering of yield, and that infection from the soil is a more important means of communication.

The soil. The soil is the principal source of the inoculum and it is when infection takes place from this source that the disease is at its worst. The results of planting healthy and diseased potatoes on land that had not produced potatoes for several years (table 3 ) show the soil to be more important than the seed as a source of the organism. After the fungus is once established in the land it becomes very persistent. and it is the opinion of the writer that if conditions are favorable it may exist there even in the absence of the potato crop for an almost indefinite length of time. In Dutchess County a field was observed which had not been plowed for seventeen years and yet when this old pasture land was planted to fusarium-free, Green Mountain potatoes from Maine in 1915 the resulting crop was uniformly diseased. In the summer of 1915 many potato fields in Dutchess County were visited and it was common to find new potato land which had been planted with unaffected seed producing a crop that showed the typical symptoms of Fusarium wilt. On the other hand it was equally common to find fields that were more or less free from the disease. This is accounted for not so much by the fact that the organism was not present but because environmental conditions were unfavorable for infection and development.

In an attempt to demonstrate that the disease is transmitted by means of infested soil the writer conducted a greenhouse experiment along the same lines as did Manns (6:316-317) and with somewhat similar results. 
In the spring of 1916 Irish Cobbler potatoes were selected that showed no internal browning of any kind. They were disinfected in corrosive sublimate 1-1000 for one and one-half hours and planted in the greenhouse in two plots of soil which came from a field in Dutchess County that produced a badly diseased crop in 1915. The soil in one of the plots, the check, had been previously sterilized by subjecting it to 15 pounds pressure of steam for one hour. There were twelve hills in each plot. At about the time when the tubers were setting, some of the plants in the unsterilized soil began to appear rather sickly but did not show the typical symptoms of Fusarium wilt as seen in the field. When the plants were removed on April 22 it was found that some of the root sys-

TABLE 4

Results of isolations from various parts of potato plants grown in sterilized and unsterilized Dutchess County soil in the greenhouse 1916

Unsterilized...............

tems in both plots were unhealthy. Three potatoes were found that had the typical stem end necrosis as seen in Dutchess County. No such tubers were found in the check plot. Isolations were made from some of the diseased plants in both plots with results as shown in table 4.

Although the isolation trials from roots grown in sterilized soil gave no Fusarium oxysporum they revealed the presence of a species of Vermicularia in amounts ranging from 15 to 75 per cent. The roots grown in the unsterilized soil showed the constant association of Fusarium oxysporum. The temperature of the greenhouse had been allowed to run at $15.5^{\circ}-18^{\circ} \mathrm{C}$. $\left(60-65^{\circ} \mathrm{F}\right.$.) during the daytime and at $10^{\circ}-13^{\circ} \mathrm{C}$. (50$55^{\circ} \mathrm{F}$.) at night, which, it should be stated, is far too low for optimum development of the fungus and disease. 
Land that has produced a diseased crop one year is practically certain to do so the next if potatoes are planted. In 1915 the writer conducted some variety and fertilizer experiments on land that had produced a diseased crop the previous year, using seed free from Fusarium. In both instances the disease was abundant in 1916, there being anywhere from 31 to 88 per cent affected tubers in the various plots. There were numerous instances of this kind observed in 1915 and 1916 where healthy seed was put on land that produced a diseased crop the year before and in no instance did the blight fail to manifest itself.

Manure and refuse. Smith and Swingle (14:53) suggested the advisability of avoiding soil contamination by means of infested manure. Orton $(9: 7)$ pointed out that dead tops and small and diseased tubers, left upon the ground furnished a breeding place for the wilt fungus. Manns (6:322) made the statement that partially rotted tubers and refuse from storage ought not to be thrown on the manure pile as it was a sure way of introducing the organism into the field.

Manure and refuse are doubtless one of the sources of the inoculum but it seems improbable that this source is an important one. These substances act as carriers of the fungus but it is believed that efficient dissemination would be accomplished even in their absence.

\section{Agents of dissemination}

Dissemination of the fungus with the seed manure and refuse, and also during the process of cultivation is attributable to man. Wind and water, however, are believed to be more important agents of dissemination. The organism is undoubtedly blown long distances along with dust. The widespread and general occurrence of the fungus in regions where the disease occurs would lead one to suspect that this was so. The washing of the infested soil by surface water from one field to the next and also the carrying and depositing of the organism by streams are probably important modes of dissemination in some places.

\section{Infection}

When the pathogene is introduced with the seed infection may take place at the base of the sprout or stalk as the vascular systems of the parent tuber and stem are in direct connection. It is possible also that the fungus may assist in rotting the seed piece and from it grow out into the soil where it is in a position to affect the roots.

When the soil is the source of the inoculum, as it most often is, the roots, especially the smaller ones, are the principal channels through 
which the fungus enters its host. It is apparent too that the organism may attack the seed from the soil and from there gain entrance to the main stem. Rhizomes and parts of the stem under ground also may be attacked directly from the soil. It is not uncommon to find young potatoes completely cut off from the parent plant because of attacks on the rhizomes. Growth cracks in the stem undoubtedly favor the penetration of the organism and numerous stem lesions, that appear to have been made by the entrance of the fungus through the unbroken epidermis, have been seen. The new tubers usually are inoculated by way of the rhizomes on which they are borne.

Within the roots the mycelium develops rapidly or slowly depending on temperature, moisture and other conditions. The hyphae apparently penetrate all tissues of the root, killing it and rendering it useless for absorption. The root becomes brownish in color in marked contrast to the ivory whiteness of those that remain healthy. The effect of the injury is manifested by a slowing of growth, a change in color of the leaves and later by a rolling or wilting of the foliage. The mycelium progresses lengthwise through the root, particularly within the xylem, which offers the path of least resistance. In this, and probably in other tissues of the root, the fungus makes its way to the main stem. The writer finds that when a diseased stem is cut the tissue that appears most affected is the phloem. It is quite dark-brown in color, due to a breaking down of the cells, particularly the sieve tubes. Because of this necrosis the underground parts of affected stems appear somewhat darkened on account of the brown, dead tissue showing through the cortex and unaffected epidermis.

The xylem appears to become affected at about the same time as the phloem. All parts may be affected, the tracheae with companion cells being the most so, and the wood cells the least. It is within the tracheae that the fungus makes its greatest progress and it is in these cells that the mycelium is most easily discerned with the microscope. The medullary rays are quick to become discolored and, as they take on a darker brown coloration than the xylem, they often show up quite conspicuously. In later stages of the disease the cortex, epidermis, and pith become successively affected. The mycelium penetrates cell walls quite readily as it can be seen extending from one cell to the next, usually through pits and thin places in the walls. The fungus does not penetrate far into the portions of the stem above ground but rather confines itself to subterranean parts. The interior of the aerial parts of the stem usually appears fairly normal to the naked eye and microscopic examination, as well as isolations such as are described in table 2, usually show the fungus to be very scarce or entirely absent at points 6 inches or more above the ground level. 
As the disease progresses the roots become completely decayed. New ones may be pushed out near the surface of the ground and above the badly diseased part. Meanwhile the majority of the leaves die, the transpiring area being reduced to equalize the absorbing surface. Such plants fall over for lack of support, linger along for some time and finally die.

Affected tubers are always borne on vines which show evidence of having Fusarium wilt. The degree of infection of the tuber varies according to the severity of the disease as it appears on the top. It commonly occurs that one stalk in a hill is diseased and another stalk is comparatively healthy, and when the whole plant is carefully removed from the soil it is found that the tubers clinging to the affected stem are diseased while those produced on the healthy part are entirely sound. Tubers of all sizes are attacked although the larger ones seem to be more liable to show deep infection.

As far as has been observed Fusarium necrosis does not increase in storage. Under warm and moist conditions affected potatoes will gradually become rotted, as will also many tubers not so affected, but the necrotic condition itself does not tend to become greater.

\section{Pathological physiology}

Theories as to the cause of necrosis of the tuber accompanying wilt of the vine. It has been mentioned that tubers affected with Fusarium wilt as it occurs in southeastern New York commonly exhibit a necrosis of the vascular system, and that usually the organism is not present in the diseased tissue except at the extreme stem end and in places that show an inintense browning. Various theories may be advanced to explain this.

It is possible that extremely unfavorable environmental conditions may be the cause of necrosis of the vascular system in the absence of any organism. For example it is now known that a condition of frost necrosis may be brought about by chilling, or frosting. It has been suggested also that overheating may possibly act in the same way as it is found that the vascular system of the tuber is the most sensitive tissue to feel the effects of adverse conditions. It has been suggested further that an insufficient water supply may result in a browning of the vessels. It seems improbable that any of these factors should be responsible for the stem end vascular necrosis that accompanies Fusarium wilt. Under natural conditions it certainly is not brought on by chilling and if heat was the causal factor one would not expect to find the disease localized in one end of the tuber nor would there be such a close relation between diseased tubers and wilted vines. It does not appear to be a water relation as it has been observed to occur under very wet as well as in very dry conditions. 
The theory that one or more toxines are responsible is much more plausible. Investigations conducted by the Federal Department of Agriculture $^{2}$ and also by the writer have shown that stem end browning can be artificially produced by feeding toxic materials in solutions at strengths too weak to kill the plant at once but of sufficient concentration to act upon the vascular system of the stem and tuber.

For injecting the solutions into plants the writer employed a method similar to that used by Miss Rumbold $(12: 225-228)$ in her work with trees. For containers, gas chimneys with two-holed rubber stoppers in the lower ends were used. Glass tubes were inserted in the two holes in each stopper and rubber tubes about $45 \mathrm{~cm}$. long were attached. In the ends of these were placed pieces of glass tubing the ends of which were bent and drawn out to capillary fineness. When in use the chimney was elevated above the plant and secured to a stake. It was then filled with the solution and the needle-like ends of the capillary tubes inserted in the stem or rhizome of the plant. Stop-cocks on the rubber tubes aided in manipulation.

To determine the possibilities of the method a weak solution of eosin was first used. In one case it was introduced through a side shoot. The dye penetrated down the stem in the water vessels of the xylem and into the old seed tuber. It also traveled up the main stem for some dist. znce but it did not go out into the newly formed tubers. When the capillary tube was inserted in the rhizome, however, the solution penetrated through the vascular ring almost to the apex of the young: tuber.

On March 15, 1916 an experiment was started as follows: 5 per cent oxalic acid was introduced into four plants; a saturated solution of salicylic acid into two plants; 1 per cent galactose into two plants; and Czapek's solution for fungi, in which Fusarium oxysporum had been growing for about three weeks, containing extra-cellular enzymes of the organism, into two plants. The capillary tubes were inserted for the most part in the lower portion of the stems although in a few cases the solutions were introduced into the rhizomes.

After six days all the plants were removed and examined. All the stems into which oxalic acid had been injected were dead, whitened, and shrunken for some distance above the point of insertion of the needle. Above the killed area the fibro-vascular bundles were blackened up into the leaflets and some of the leaves showed a spotting of the parenchyma between the smaller veins. The vascular ring of one tuber, borne on a plant into the stems of which oxalic acid had been introduced, was

${ }^{2}$ Unpublished information gained from conversation with Drs. H. A. Edson, W. A. Orton, and others. 
browned inward for some distance and resembled very much the internal browning accompanying Fusarium wilt. Some of the tubers borne on rhizomes that were injected with oxalic acid showed a similar condition (plate XV, fig. B).

Stems into which salicylic acid was introduced showed dead and shrunken areas in the immediate vicinity of the needle, with one of the primary bundles blackened for a distance of about $8 \mathrm{~cm}$. The tubers did not seem to be much affected with this substance. Galactose at the concentration used was without appreciable effect. The solution in which the fungus had grown gave good results. When inoculated into rhizomes not far from growing tubers the vascular system of these organs and of the tubers became affected and the latter showed a brown ring as seen in Fusarium wilt, but the condition resembling net-necrosis was not reproduced. The inoculum was prepared by growing Fusarium oxysporum in Czapek's solution for about three weeks at the end of which time the fungus was removed and the liquid medium containing the enzymes that had been excreted by the mycelium during its growth was filtered off. It had a noticeably bitter taste at this time. No attempt was made to keep the extract sterile after it was filtered nor while it was being injected into the plant. There was no growth of any kind on the surface during the length of the experiment.

From these results it is evident that certain toxic substances when introduced into the vascular system of a growing potato tuber may cause a browning of the vessels. It seems probable that stem end necrosis with its absence of any organism can be explained on this basis.

The toxic material involved may be excretions of the fungus, as has been shown by the foregoing experiment, or it may consist of decomposition products from dead host cells. In Overton's (11) work on the relation of living cells to the ascent of sap it will be recalled that he had occasion to kill portions of Cyperus stems with steam. He found that leaves on stems so killed did not wither as quickly as did cut stems in water, but when they did die they showed all the symptoms of being poisoned rather than simply deprived of water. When steamed stems were split lengthwise numerous dark streaks or lines could be seen with the naked eye in the vascular tissue above the killed portion, reaching almost to the leaves in some cases. The streaks followed the fibro-vascular bundles and ranged in color from black to brown and yellow. The phloem was the part that was most deeply colored, apparently due to a disorganization of the sieve-tubes. A mucilage or gum-like substance which in some cases plugged the xylem vessels was observed to be present in the tissue above the killed portion. 
In the spring of 1916 the writer killed potato stems with steam. The lower portions of stems of plants growing in the greenhouse were killed by steaming them in a glass chamber such as was used by Overton and also by simply playing a jet of steam on the part to be killed. The leaves on plants so treated stayed quite turgid for a number of days. One of the plants continued to appear normal for four days after treatment, and then the leaves finally showed the effects by slowly wilting, turning yellow and finally by dying. Some of the leaves showed a mottling of dark and light green not unlike mosaic and one plant produced aerial tubers in the axils of the leaves all the way up the stems. When the stems were split open most of the plants showed a blackening of some of the bundles above the lesions and in one case a browning of the bundles of a tuber was observed.

These observations show that the decomposition products of potato cells which have been. killed by steam are able to discolor the watercarrying tissue and are probably toxic to it. It is believed that the toxin theory is the most plausible explanation for vascular discoloration in potato tubers borne on affected plants. The root, stem and rhizome tisiues are diseased and many cells are dead. The plant, however, continues to function at a low ebb. The yellowed and small leaves continue to synthesize carbohydrates which are transported to the tubers through vessels that are thoroughly diseased. Toxic products from decomposing cells and from fungus mycelium become mixed with the sap and are transferred with it to the tuber where they affect the net-like system of tracheal tubes. The result is a stem end net-necrosis with no organism present.

Further theories as to the cause of wilting. During the summer of 1915 the writer carried on a small experiment that further substantiates the conclusions of Overton (11) and Dixon (3:68) that products of plant cells are toxic to the plants themselves and that wilting may be due to the introduction of poisonous or plasmolyzing substances into the transpiration sap. Cut stems of potato plants were placed in bottles containing extract of ground pulp from healthy and from diseased potato tubers. The extract was prepared by grinding the potatoes, washing with tap water, and filtering out the diluted juice. The bottles were arranged in series as follows:

Series 1. Three bottles, 150 cc. tap water in each.

Series 2 . Three bottles, 150 cc. tap water containing extract of healthy potatoes.

Series 3. Three bottles, $150 \mathrm{cc}$. tap water containing extract of potatoes affected with Fusarium necrosis. 
Fresh shoots were placed in the solutions and at the end of nineteen hours the following notes were taken:

Series 1. All plants erect, turgid, and as fresh as if growing in field.

Series 2. Decided wilt. Stems very flaccid, tops bending over and touching table.

Series 3. Decided wilt, about the same as series 2.

This experiment coupled with the result of other investigations $(11,3)$ leads one to suspect that the extract from both diseased and healthy tubers had a poisonous effect on the green shoots.

Certain wilt diseases of plants, Fusarium wilt of potato included, have been attributed to direct stoppage of the vessels with hyphae of the respective causal fungi, thus shutting off the supply of water to the leaves. This may be a factor in some cases but it has very little effect as far as Fusarium wilt of potato is concerned. The writer has examined the stems of many plants microscopically and found no instance of a stoppage of the trachea sufficient to shut off the passage of sap. The destruction of the roots is enough in itself to explain the rolling, wilting and death of the leaves and that is believed to be the primary reason for the early death of affected plants.

\section{ECOLOGY}

\section{Influence of climatic factors}

Temperature. It is well known that the potato plant needs a cool growing season for its best development. High summer temperatures do not obtain in its native habitat in the mountainous regions of Peru and Chili, and the plant is found growing most vigorously and producing the largest yields in the northernmost and coolest parts of the United States. It is true that potatoes are successfully grown in certain parts of the southern states but in these places the greater part of the crop is grown during the early and cool part of the season and early varieties are used especially. In this way the crop is matured before the hottest weather of the summer. The yields obtained are not large and it is the high price that is annually secured for an extra early product that makes the crop profitable.

In the northern part of New York yields of 300 and 400 bushels per acre are not uncommon while in the lower Hudson Valley 200 bushels are exceptional. This is due chiefly to the higher temperature in the latter region. An examination of the temperature records of the United States Weather Bureau shows that the hottest part of the state during the summer is from Poughkeepsie south to New York City. 
It has already been pointed out that Fusarium oxysporum was able to resist high temperatures and that it makes its optimum growth at temperatures of $26^{\circ}-32^{\circ} \mathrm{C}$. $\left(79^{\circ}-89^{\circ} \mathrm{F}\right.$.) and its maximum is in the neighborhood of $40^{\circ} \mathrm{C}$. $\left(104^{\circ} \mathrm{F}\right)$. It is evident then that hot weather is unfavorable for the host but is favorable for the parasite. Furthermore it appears that it is during hot weather that the wilt develops and it is noticeable that the disease occurs in places where high summer temperatures prevail. In the United States it is most common all along the southern border of the late potato regions. In New York it is especially in the southeastern part, and somewhat, although not so common, in the western, central and southern sections. In Dutchess County it is most severe in the southwestern part where the summer temperature is the highest. The village of Wappingers Falls, Dutchess County is about in the center of the region where the disease is worst. At this place is located one of the United States Weather Bureau cooperative stations. It is interesting to compare the summer temperatures here with the average of the Hudson River Valley and of the state (table 5).

It will be seen that the temperatures at Wappingers Falls are about the highest in the Hudson Valley Division which includes the counties of Albany, Greene, Saratoga, Putnam, Columbia, Warren, Rensselaer, Fulton, Dutchess, and Orange. It is further evident from the table that the highest monthly mean temperatures in the state are registered in the Southern Hudson Valley at stations from Troy south to New York City. In 1914 the highest temperatures in the state for the months of September and October were recorded at Wappingers Falls. Manns (6 : 319) gives the mean temperatures at Wooster, Ohio, for June, July, August and September of the years 1908, 1909 and 1910 when Fusarium wilt was serious. The figures are very much like those for the mean temperatures during the same months at Wappingers Falls, Dutchess County in the years 1914 and 1915, in fact the average means for the seasons are nearly all alike.

Within Dutchess County a distinct correlation between altitude and amount of disease was noticed. Fusarium wilt might be severe on the lowlands near sea-level but a few miles distant up on the hills and ridges at an altitude of about 1000 feet the disease was rare. From conversations with farmers it was learned that larger yields were obtained on the highlands and that in those places Fusarium wilt had never been a serious factor. This variation in amount of disease is attributable principally to difference in temperature. In an effort to determine how much variation in temperature could be expected at higher and lower levels in the county, temperature records were taken on Chestnut Ridge at an altitude of 1140 feet and at Rochdale, a place 14 miles further west, which is 200 feet above sea-level. The results are given in table 6 . 
TABLE 5

Summer temperatures at Wappingers Falls, New York, compared with the average for the Hudson River Valley and for the state, 1914 and 1915

\begin{tabular}{|c|c|c|c|c|c|c|}
\hline \multirow{2}{*}{ MONTH } & \multicolumn{3}{|c|}{ WAPPINGERS FALLS } & \multicolumn{3}{|c|}{ HUDSON VALLEY DIVISION } \\
\hline & Mean & Highest & Lowest & Mean & Highest & Lowest \\
\hline 1914 & & & & & & \\
\hline June............. & 68.0 & 96 & 42 & 65.5 & 97 & 38 \\
\hline July....... & 70.9 & 91 & 48 & 69.1 & 93 & 42 \\
\hline 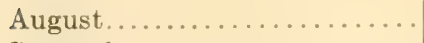 & 72.9 & 97 & 50 & 69.5 & 97 & 39 \\
\hline September............... & 64.2 & 99 & 28 & 61.7 & 99 & 20 \\
\hline Average...$\ldots \ldots \ldots \ldots \ldots$ & 69.0 & & & 66.4 & & \\
\hline 1915 & & & & & & \\
\hline June............ & 68.0 & 92 & 40 & 65.5 & 92 & 34 \\
\hline July............ & 72.0 & 94 & 50 & 70.3 & 94 & 45 \\
\hline 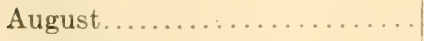 & 69.4 & 90 & 46 & 67.2 & 91 & 40 \\
\hline September................ & 67.6 & 94 & 35 & 66.2 & 94 & 29 \\
\hline Average...$\ldots \ldots \ldots \ldots$ & $(9.2$ & & & 67.3 & & \\
\hline
\end{tabular}

New York State

\begin{tabular}{|c|c|c|c|c|c|c|}
\hline \multirow{2}{*}{ MONTH } & \multirow{2}{*}{ MEAN } & \multicolumn{2}{|c|}{ HIGHEST TEMPERATURE IN STATE } & \multirow{2}{*}{ LOWEST } & \multicolumn{2}{|c|}{ HIGHEST MONTHLY MEAN } \\
\hline & & $\begin{array}{c}\text { Temper- } \\
\text { ature }\end{array}$ & Place & & $\begin{array}{c}\text { Temper- } \\
\text { ature }\end{array}$ & Place \\
\hline 1914 & & & & & & \\
\hline June........... & 63.6 & 99 & Mount Hope & 29 & 69.8 & West Point \\
\hline July.......... & 68.2 & 98 & Troy & 31 & 72.8 & Troy \\
\hline August......... & 67.7 & 103 & Fayetteville & 30 & 73.7 & New York \\
\hline September..... & 59.6 & 99 & Wappingers Falls & 18 & 67.3 & Citchogue \\
\hline Average....... & 64.8 & & & & & \\
\hline 1915 & & & & & & \\
\hline June... .... & 63.1 & 94 & Brockport & 30 & 68.3 & Mount Hope \\
\hline July..... . . . & 68.0 & 95 & West Berne & 23 & 73.2 & West Point \\
\hline August...... & 65.5 & 94 & Bedford Hills & 29 & 71.6 & Bedford Hills \\
\hline September..... & 63.9 & 95 & West Berne & 24 & 69.0 & West Point \\
\hline Average. & 65.1 & & & & & \\
\hline
\end{tabular}

It will be seen that as a rule it was cooler at the higher altitude. The temperature there was more uniform and at no time did the thermometer go above $95^{\circ} \mathrm{F}$. while at the 200 foot level the temperature rose to $100^{\circ} \mathrm{F}$. at four different times. 
TABLE 6

Record of temperatures at Rochdale, Dutchess County, altitude 200 feet, compared with those at Chestnut Ridge, 14 miles east, altitude 1200 feet. July 25, to A ugust 27, 1916

\begin{tabular}{|c|c|c|c|c|}
\hline \multirow{2}{*}{ DATE } & \multicolumn{2}{|c|}{ MaXIMUM } & \multicolumn{2}{|c|}{ MINIMLM } \\
\hline & Rochdale & $\begin{array}{c}\text { Chestnut } \\
\text { Ridge }\end{array}$ & Rochdale & $\begin{array}{c}\text { Chestnut } \\
\text { Ridge }\end{array}$ \\
\hline & $\operatorname{deg} . F$. & $\operatorname{deg} . F$. & $\operatorname{deg} . F$ & $\operatorname{deg} . F$. \\
\hline July $25 \ldots \ldots \ldots \ldots \ldots \ldots \ldots \ldots$ & 82 & 78 & 65 & 65 \\
\hline July $26 \ldots \ldots \ldots \ldots \ldots \ldots \ldots$ & 75 & 71 & 65 & 64 \\
\hline July $27 \ldots \ldots \ldots \ldots \ldots \ldots \ldots \ldots$ & 90 & & 70 & \\
\hline July $28 \ldots \ldots \ldots \ldots \ldots \ldots \ldots \ldots$ & 85 & 74 & 62 & 62 \\
\hline July $29 \ldots \ldots \ldots \ldots \ldots \ldots \ldots \ldots$ & 80 & 79 & 46 & 53 \\
\hline July $30 \ldots \ldots \ldots \ldots \ldots \ldots \ldots \ldots$ & 63 & 82 & 57 & 68 \\
\hline July $31 \ldots \ldots \ldots \ldots \ldots \ldots \ldots$ & 87 & 89 & 64 & 69 \\
\hline August $1 \ldots \ldots \ldots \ldots \ldots \ldots \ldots$ & 84 & 77 & 57 & 59 \\
\hline August $2 \ldots \ldots \ldots \ldots \ldots \ldots \ldots$ & 87 & 83 & 48 & 53 \\
\hline August $3 \ldots \ldots \ldots \ldots \ldots \ldots \ldots$ & 83 & 86 & 49 & 53 \\
\hline August $4 \ldots \ldots \ldots \ldots \ldots \ldots \ldots$ & 90 & 83 & 59 & 60 \\
\hline August $5 \ldots \ldots \ldots \ldots \ldots \ldots \ldots \ldots$ & 90 & 85 & 66 & 65 \\
\hline August $6 \ldots \ldots \ldots \ldots \ldots \ldots \ldots \ldots$ & 100 & 88 & 70 & 69 \\
\hline August $7 \ldots \ldots \ldots \ldots \ldots \ldots \ldots \ldots$ & 97 & 89 & 70 & 68 \\
\hline August $8 \ldots \ldots \ldots \ldots \ldots \ldots \ldots \ldots$ & 100 & 91 & 75 & 67 \\
\hline August $9 \ldots \ldots \ldots \ldots \ldots \ldots \ldots \ldots$ & 89 & 77 & 67 & 63 \\
\hline August $10 \ldots \ldots \ldots \ldots \ldots \ldots \ldots \ldots$ & 65 & 63 & 57 & 53 \\
\hline August $11 \ldots \ldots \ldots \ldots \ldots \ldots \ldots$ & 73 & 71 & 54 & 53 \\
\hline August $12 \ldots \ldots \ldots \ldots \ldots \ldots \ldots$ & 90 & 87 & 60 & 60 \\
\hline August $13 \ldots \ldots \ldots \ldots \ldots \ldots \ldots$ & 73 & 73 & 53 & 49 \\
\hline August $14 \ldots \ldots \ldots \ldots \ldots \ldots \ldots \ldots$ & 81 & 75 & 39 & 46 \\
\hline August $15 \ldots \ldots \ldots \ldots \ldots \ldots \ldots$ & 85 & 86 & 44 & 52 \\
\hline August $16 \ldots \ldots \ldots \ldots \ldots \ldots \ldots \ldots \ldots \ldots \ldots \ldots \ldots$ & 89 & 87 & 51 & 52 \\
\hline August $17 \ldots \ldots \ldots \ldots \ldots \ldots \ldots$ & 92 & 82 & 57 & 63 \\
\hline August $18 \ldots \ldots \ldots \ldots \ldots \ldots \ldots$ & 93 & 89 & 54 & 60 \\
\hline August $19 \ldots \ldots \ldots \ldots \ldots \ldots \ldots \ldots$ & 95 & 86 & 56 & 60 \\
\hline August $20 \ldots \ldots \ldots \ldots \ldots \ldots \ldots \ldots$ & 97 & 86 & 55 & 61 \\
\hline August $21 \ldots \ldots \ldots \ldots \ldots \ldots \ldots \ldots$ & 100 & 89 & 54 & 60 \\
\hline August $22 \ldots \ldots \ldots \ldots \ldots$ & .101 & 87 & 62 & 68 \\
\hline August $23 \ldots \ldots \ldots \ldots \ldots \ldots \ldots$ & 100 & 94 & 63 & 62 \\
\hline August $24 \ldots \ldots \ldots \ldots \ldots \ldots$ & 77 & 70 & 60 & 58 \\
\hline August $25 \ldots \ldots \ldots \ldots \ldots \ldots \ldots$ & 86 & 83 & 44 & 53 \\
\hline August $26 \ldots \ldots \ldots \ldots \ldots \ldots \ldots \ldots \ldots \ldots \ldots \ldots$ & 88 & 82 & 54 & 59 \\
\hline August $27 \ldots \ldots \ldots \ldots \ldots \ldots \ldots \ldots \ldots$ & 87 & 81 & 59 & 59 \\
\hline Average for 34 days.............. & 85.7 & 79.2 & 56.9 & 59.6 \\
\hline
\end{tabular}

The writer has noticed a tendency for Fusarium wilt to occur more abundantly on southern than on northern exposed fields. Bouyoucos (1:125) has shown that a southern exposure of a field considerably influences soil temperature. According to him a southern exposure had 
about $2^{\circ} \mathrm{F}$. higher average temperature than a northern during the spring and summer months of 1915. Bouyoucos (1:132) has also demonsstrated that shade has a very large controlling influence upon soil temperature. The writer has made observations showing that Fusarium wilt is reduced by shade. In 1916, a potato field was observed on the edge of which stood a tall elm tree that cast a shadow during the middle of the day on some of the vines in the vicinity. The plants thus shaded were green and only slightly affected with Fusarium wilt while other plants in the same field were entirely dead from this disease and tip-burn. It is believed that the soil moisture relation did not enter in as an influencing factor in this case. In 1916 the writer kept continuous temperature records by means of a soil and air thermograph. It was found that shade afforded the soil by potato vines was considerable. The maximum temperature of unshaded soil, at a depth of 4 inches, was $9^{\circ} \mathrm{F}$. higher than soil that was shaded by vines. It was found that covering the soil with a straw mulch greatly tends to keep down and to equalize soil temperature.

These facts coupled with the results of infection experiments in the greenhouse, where the temperature was controlled, lead to the belief that temperature is probably the most important factor limiting the development of Fusarium wilt in southeastern New York. It is thought that the organism is widespread in many soils and that in the majority of cases it only awaits the presence of the potato crop and the proper temperature conditions to develop.

Rainfall. It is believed that the amount of rainfall has very little to do with the prevalence of the disease. In the year 1915 when there was an abundant supply of moisture to the plants Fusarium wilt occurred to about the same extent that it did in the summers of 1914 and 1916 when there was dry weather. It seems, however, that under conditions of drought diseased plants will succumb quicker than when supplied with sufficient water.

\section{Influence of soil factors}

Fusarium wilt in New York is not confined to any particular type of soil although it appears to be more common on the lighter sandy soils than on heavier clayey ones. Orton $(10: 8)$ pointed out that Fusarium wilts of cotton, watermelon, and cowpea occurred principally on sandy and sandy loam soils but that such was the case with potato wilt was not certain, although the evidence indicated that the plants on light soils were more liable to infection. In New York potatoes on clayey soils are affected but usually not so badly as on the other more sandy types. It is believed that the relation of soil type to disease is princi- 
pally because of differences in temperature. Clay soils have a greater water-holding capacity and are cooler on that account. Sandy soils are not able to hold so much water and are therefore hotter. Dark colored soils like muck would naturally become warmer than light colored ones on account of their heat absorbing capacity but this may be offset by the large water content.

It was believed in the early part of this work that certain chemical properties of the soil might be influential in bringing on stem end netnecrosis of the tuber. Various types of internal browning occurring both in the United States and Europe have been ascribed to malnutrition and unfavorable soil conditions. Certain of these troubles have been attributed to lack of potash, lime, or phosphate while some workers have thought an excess of iron was responsible. In order to test the effect of various soil treatments on the disease a strip of land, 10 by

TABLE 7

Results of planting healthy seed on infested land in Dutchess County, the soil being treated with various fertilizers

\begin{tabular}{|c|c|c|}
\hline TREATMENT & $\begin{array}{c}\text { AVERAGE } \\
\text { WEIGHT PER } \\
\text { HILL }\end{array}$ & $\begin{array}{l}\text { DISEASED } \\
\text { TUBERS }\end{array}$ \\
\hline & ounces & per cent \\
\hline 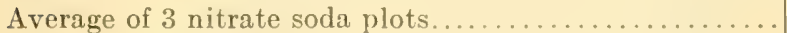 & 6.1 & 43 \\
\hline 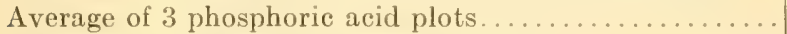 & 14.7 & 77 \\
\hline 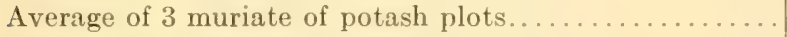 & 6.0 & 63 \\
\hline Average of 3 complete fertilizer plots.......... & 9.07 & 71 \\
\hline 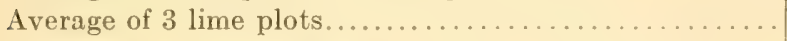 & 9.2 & 72 \\
\hline Average of 15 check plots... & 8.79 & 67 \\
\hline
\end{tabular}

100 yards, was selected in a field where there has been considerable of this trouble the year before. The strip was divided into plots running crosswise, and disinfected; fusarium-free, Green Mountain potatoes were planted. The fertilizers were placed in the furrow and mixed with the soil before the seed was dropped. Check plots were placed between each test plot and the experiment was run in triplicate. The substances used and a summary of the results obtained are given in table 7 .

The results obtained are in accord with those of Smith and Swingle (14:27) who carried on extensive fertilizer experiments, using many different substances and in varying amounts. As will be seen in table 7 none of the various treatments had any appreciable effect on the amount of disease. The percentages were obtained by eutting through the stem end of every potato in the center row of each plot. A large proportion of tubers in all plots showed typical Fusarium necrosis. 
CONTROI

\section{Crop rotation}

It has been advised by various workers that rotation of crops will aid in keeping down the disease. Manns (6:333) recommended the allowance of at least five or six years between successive crops, Orton (10:14-15) advised five to eight years, and Smith and Swingle (14:53) pointed out the advisability of crop rotation but mentioned no definite period. After seeing so many outbreaks of Fusarium wilt on new potato land where clean seed was planted, the writer is inclined to doubt the value of rotation as a method of control. Attention has already been called to a field which had not been planted to potatoes for seventeen years and practically every plant in which became affected. In New York state the fungus appears to be generally distributed over large areas and seems to be very persistent when once established. Apparently it only awaits the potato crop and favorable conditions to become destructive.

It is believed, as a matter of general principle, and in order to hinder the development of the fungus as much as possible, that a wide rotation of the potato crop is advisable in sections where Fusarium wilt is liable to occur. Certainly in such locations potatoes should not be planted two years in succession on the same piece of land.

\section{Elimination of diseased tubers or parts of tubers}

It is advised that the use of diseased potatoes be avoided in the majority of cases. Not only is it possible that the fungus may be transmitted from one crop to the next in this way and the soil become more thoroughly infested by so doing, but, as has been pointed out, the sprouts of potato tubers affected with Fusarium necrosis are weakened and the resulting plants are not so strong, nor is the yield so great, as when healthy seed is used (table 3).

It is advised that wherever possible northern grown, fusarium-free seed be secured for planting, but, in case native seed is used, the following procedure is recommended. Representative samples should be taken from the stock under consideration for planting and an examination made by clipping slices from the stem end of a number of tubers. If a considerable percentage ( 5 per cent or over) of the tubers are found having marked Fusarium necrosis it is believed that the entire stock should be rejected for seed purposes. If only a small percentage is found the seed may be good for planting, providing the badly diseased tubers are removed. This may be largely accomplished in two ways, (1) by 
germinating or "greening" the potatoes for a few weeks before they are planted and then using only those tubers that show strong germinative power for seed, or, (2) in case the seed is to be cut as it usually is in Dutchess County, the stem end of each tuber may be clipped during the process of cutting and diseased tubers discarded. It is believed that the "greening" process mentioned above, in which the potatoes are spread out in a dry light place two to three weeks in advance of planting, is worth while anyway as it insures the use of strong seed and gives a quicker come-up and earlier yield, a factor which in itself, as will be shown later, is helpful in avoiding the disease. In case slightly diseased cut seed is being used for planting it is believed desirable to remove and reject the stem end of all tubers during the cutting operation. It does not take much longer, it shows to what extent the tuber is affected, and it frees the seed piece from the diseased part where the organism may be harbored. If the buds on potatoes that show ring infection appear strong there is no reason why the healthy part should not be planted provided the entire diseased portion is removed. It might be safer not to use such seed as a number of other diseases of a more communicable character produce a somewhat similar ring discoloration. On the other hand if one is familiar with the disease and the seed is otherwise good it would doubtless be economy to plant the healthy and vigorous appearing portion as suggested.

Along with inspection should go seed treatment to kill various pathogens including Fusarium on the exterior. Manns (6:332) recommends disinfection after the stem ends have been removed but on account of possible injury through the cut surface it would seem much more preferable that the treatment precede cutting. Dusting the cut seed with sulfur flour or flowers of sulfur is believed to be advisable both as a general cultural practice and because of possible disinfecting properties against Fusarium.

\section{Disease resistant varieties}

In the case of a number of other plant diseases of this nature such as cotton wilt, cowpea wilt, and cabbage yellows the development and growing of resistant plants has offered the most satisfactory, and in some cases the only method of effective control. It is probable that in time varieties of potatoes resistant to Fusarium wilt will be secured by selection or hybridization but thus far none have been obtained.

The writer has made trials with a few varieties on infested soil in Dutchess County. On May 25, 1915, five different varieties of potatoes were planted on land that had produced a badly diseased crop the year before. It was made certain that the seed was free from any vascular 
browning by clipping off the basal end of each seed tuber before planting. When harvested, September 14, the yield and amount of Fusarium stem end browning was ascertained and is given in table 8 .

It will be seen that all the varieties were badly diseased, none of them showing promise of being resistant. It is interesting to note however that the Triumph, a very early variety, and usually considered to be a low yielder as compared with later varieties, gave by far the largest yield, in spite of the fact that the tubers were affected. This is believed to be on account of its having practically reached maturity at the time when the disease became severe.

The following season forty varieties of potatoes representing nine different groups as classified by Stuart (16) were planted on two different plots of infested land, one at Arlington and one at East Fishkill, New York, both in Dutchess County. Owing to wet weather it

TABLE 8

A test of varietal susceptibility to Fusarium wilt of potato in Dutchess County, 1915. Healthy potatoes were planted on infested land

\begin{tabular}{|c|c|c|c|c|c|c|c|}
\hline \multirow{2}{*}{ VARIETY } & \multirow{2}{*}{$\begin{array}{l}\text { WEIGHT } \\
\text { OF } \\
15 \text { HILLS }\end{array}$} & \multirow{2}{*}{$\begin{array}{l}\text { TOTAL } \\
\text { TUBERS }\end{array}$} & \multicolumn{3}{|c|}{$\begin{array}{l}\text { AMOUNT OF STEM-END } \\
\text { INFECTION }\end{array}$} & \multirow{2}{*}{$\begin{array}{l}\text { TOTAL } \\
\text { NUMBER } \\
\text { OF } \\
\text { DISEASED } \\
\text { TUBERS }\end{array}$} & \multirow{2}{*}{$\begin{array}{l}\text { DISEASED } \\
\text { TUBERS }\end{array}$} \\
\hline & & & $\mathrm{Bad}$ & Slight & None & & \\
\hline & pounds & & & & & & per cent \\
\hline No. 9 . & 12.0 & 66 & 6 & 25 & 35 & 31 & 47 \\
\hline Triumph.... & 20.5 & 73 & 6 & 34 & 33 & 40 & 55 \\
\hline Rural New Yorker.. & 14.5 & 48 & 12 & 22 & 14 & 34 & 71 \\
\hline Bovee............ & 4.0 & 83 & 52 & 21 & 10 & 73 & 88 \\
\hline Green Mountain............ & 9.0 & 61 & 16 & 19 & 26 & 35 & 51 \\
\hline
\end{tabular}

was not possible to plant before June 12 and June 15, respectively. At digging time all of the varieties showed some affection of the tubers. All of them were susceptible. Of course there was a large variation in the yield of the separate varieties but it was impossible to tell whether or not any of the differences were due to resistance. It was observed that some of the earlier varieties made a good yield compared with the later ones and it is believed that if the planting had been earlier some of these would have proved the most satisfactory.

\section{Disease escaping varieties and the date of planting}

It has been noticed that Fusarium wilt does not begin to appear on the vines until the middle of the summer when the temperatures are the hottest. In the Hudson Valley this is usually from the middle of 
July to the middle of August. At this time early potatoes that have been planted early will be approaching maturity while late potatoes of the Green Mountain or Rural New Yorker types are just setting tubers. The result is that when the vines are dead the yield from the early varieties will be fairly normal while that from the late potatoes is greatly reduced. The case just mentioned of the superior yield of Triumph in 1915 illustrates this point. On one farm in Dutchess County, for the past two seasons, Irish Cobblers, planted early, have yielded 180 bushels to the acre as compared with 98 bushels for Green Mountains planted later.

It is a common practice in the Hudson Valley, where potatoes are a relatively unimportant crop, to postpone putting in the seed until the last of the spring planting. A good crop is sometimes secured in this way but too often it happens that the vines are killed early by wilt, when the tubers are small. Uniformly better results would be secured by planting an early potato like the Irish Cobbler and planting it as early as possible in order to mature a crop before the hot weather of the middle of August. In Dutchess County the climatic conditions are similar to those of some of the early trucking regions further south and the potato growing methods carried out there, especially the early planting of Irish Cobblers, should be more closely followed. The writer is strongly of the opinion that a change in the cultural practice such as has just been outlined is probably the most promising and practical way of dealing with the Fusarium wilt problem in southeastern New York.

\section{SUMMARY}

The destructive potato disease of uncertain identity in the southern Hudson River Valley has been found to be Fusarium wilt.

The symptoms of the disease as it occurs in this locality are practically the same as described by other writers except that the tubers commonly exhibit a condition in which the vaseular system near the stem end is browned without the causal organism necessarily being present, and which is designated here as "Fusarium necrosis." These potatoes are always produced on plants that are affected with Fusarium wilt. When they germinate they produce spindling sprouts.

Isolations and microscopic examination have been made that show the fungus to be frequently present in the extreme stem end of tubers affected with Fusarium necrosis but entirely absent or very rare in the diseased tissue of the interior of such tubers. The pathogene is most abundant in the roots, rhizomes and lower parts of the stem. It is not commonly present in the upper portions of freshly wilted plants. 
That Fusarium oxysporum is the primary cause of the disease, is shown by the constant association of the organism with the host, and by the artificial production of the disease with the use of pure cultures, sterilized seed and sterilized soil.

Planting experiments, both in Dutchess County and at Ithaca, N. Y., show that the pathogene may be communicated, to some extent at least, through seed tubers affected with Fusarium necrosis, but on the other hand, affected tubers often produce a crop apparently free from Fusarium wilt or necrosis. The plants arising from such potatoes however are weak and the yield is small so that the use of diseased seed cannot be recommended even through the resulting crop may be healthy.

The soil is the principal source of the inoculum in Dutchess County. The disease is most destructive when infection takes place by reason of the potatoes being planted in infested land.

Experiments were conducted in an effort to discover possible reasons for a necrosis of the tuber in the absence of any organism. Certain toxic solutions, such as 5 per cent oxalic acid, and a liquid extract of Fusarium oxysporum, when introduced into the rhizome of the growing tuber were found to produce a non-parasitic browning of the potato not unlike Fusarium necrosis. A discoloration of the xylem in the stem was also produced by killing a portion of the stem with steam, showing that the products of decomposing cells have a poisonous effect. It seems likely therefore that the apparently non-parasitic affection of the tuber accompanying Fusarium wilt may be explained on the basis of the presence of toxines.

The following evidence is given to show that temperature is a very important factor in the development of Fusarium wilt.

1. Fusarium oxysporum makes its best growth at comparatively high temperatures $\left(26^{\circ}-32^{\circ} \mathrm{C}\right.$. optimum and $40^{\circ} \mathrm{C}$. maximum), while the potato plant develops most luxuriously in a relatively cool climate. In Dutchess County temperature conditions exist that are favorable for the parasite and unfavorable for the host with the result that the disease develops to an unusual extent.

2. The disease appears annually in New York during the hot weather of the latter part of July or the first of August.

3. Within Dutchess County, and also within New York state and the United States, the disease is most severe in places where high summer temperatures prevail at the time when tuber formation is in progress.

4. Within Dutchess County there is a distinct correlation between the amount of disease and factors influencing soil temperature such as altitude, exposure of fields and shading of plants. 
5. Early attempts to produce the disease artificially yielded only unsatisfactory, sporadic, or negative results because of failure to recognize the importance of proper soil temperature. When this was taken into account however, and plants were grown at temperatures of $36^{\circ} \mathrm{C}$. $\left(97^{\circ} \mathrm{F}\right.$.) positive results were obtained.

Soil moisture, soil type and soil fertility while undoubtedly influencing the disease to some extent are not found to be nearly so important in this respect as is soil temperature.

Crop rotation, under Dutchess County conditions, is of doubtful value as a practical means of control. It is recommended as a good cultural practice but it does not seem to have any great influence on the amount of disease.

No varietal resistance was noted, and various fertilizers appeared to have no influence on the amount of disease.

The most practical solution of the problem in Dutchess County seems to be the planting of early potatoes such as Irish Cobbler very early in the season so that the crop is matured before temperature conditions are favorable for Fusarium wilt.

Cornell University, Ithaca, New York

\section{LITERATURE CITEI)}

(1) Bouroucos, G. J.: Soil temperature. Michigan Agr. Expt. Sta. Tech. Bul. 26: 5-133. 1916.

(2) Carpenter, C. IV.: Some potato tuber-rots caused by species of Fusarium. Jour. Agr. Research, 5: 183-210, pl. A-B, 14-19. 1915. Literature eited, p. 208-209.

(3) Dixon, H. H.: Transpiration and the ascent of sap in plants. 216 p., illus. London, 1914.

(4) Jones, L. R., and Gimman, J. C.: The control of cabbage yellows through disease resistance. Wisconsin Agr. Expt. Sta. Research Bul. 38, 70 p., 23 fig. 1915. Literature cited, p. 69-70.

(5) Link, G. K. K.: A physiological study of two strains of Fusarium in their causal relation to tuber rot and wilt of potato. Nebraska Agr. Expt. Sta. Research Bul. 9, 45 p., illus. 1916. Also published in Bot. Gaz. 62: 169-209, illus. 1916.

(6) Manns, T. F.: The Fusarium blight (wilt) and dry rot of the potato. Ohio Agr. Expt. Sta. Bul. 229: 299-337, pl. 1-15. 1911.

(7) Orton, IV. A.: The wilt disease of the cowpea and its control. U. S. Dept. Agr. Bur. Plant Indus. Bul. 17: 9-22. 1902.

(8) Orton, W. A.: Cotton wilt. U. S. Dept. Agr. Farmers' Bul. 333, 24 p., illus. 1908.

(9) Orton, W. A.: Potato diseases in San Joaquin county, California. U. S. Dept. Agr. Bur. Plant Indus. Circ. 23, 14 p. 1909.

(10) Orton, W. A.: Potato wilt, leaf-roll, and related diseases. U. S. Dept. Agr. Bul. 64,48 p., 16 pl. 1914. Bibliography, p. 44-48. 
(11) Overton, J. B.: Studies on the relation of the living cells to transpiration and sap-flow in Cyperus. Bot. Gaz., 51: 28-63, fig. 1; 102-120, fig. 2-3. 1911.

(12) Rumbold, Caroline: Methods of injecting trees. Phytopathology, 5: 225228, pl. 13. 1915 .

(13) Sherbakoff, C. D.: Fusaria of potatoes. New York Cornell Agr. Expt. Sta. Mem., 6: 87-270, 51 fig., 7 col. pl. 1915. Literature cited, p. 269-270.

(14) Smith, Erwin F., And Swingle, D. B.: The dry rot of potatoes due to Fusarium oxysporum. U.S. Dept. Agr. Bur. Plant Indus. Bul. 55, 64 p., 8 pl. 1901. Literature, p. 61-62.

(15) Stewart, F. C.: Another stem blight of potatoes. New York State Agr. Expt. Sta. Bul. 101: 83-84. 1896.

(16) Stewart, F. C.: The communicability of stem blight. New York State Agr. Expt. Sta. Bul. 138: 632-634. 1897.

(17) Stuart, William: Group classification and varietal deseriptions of some American potatoes. U. S. Dept. Agr. Bul. 176, 56 p., 19 pl. 1915.

(18) Wollenweber, H. W.: Studies on the Fusarium problem. Phytopathology, 3: 24-50, pl. 5. 1913.

\section{PLATE XIII}

FIG. A. A plant of the Green Mountain variety affected with Fusarium wilt. One stalk is badly diseased and the other only slightly so.

FIG. B. Two germinating potato tubers from the same source and of the same variety. The one on the left is healthy while the one on the right is affected with Fusarium necrosis. The difference in the size of the sprouts is very noticeable. 


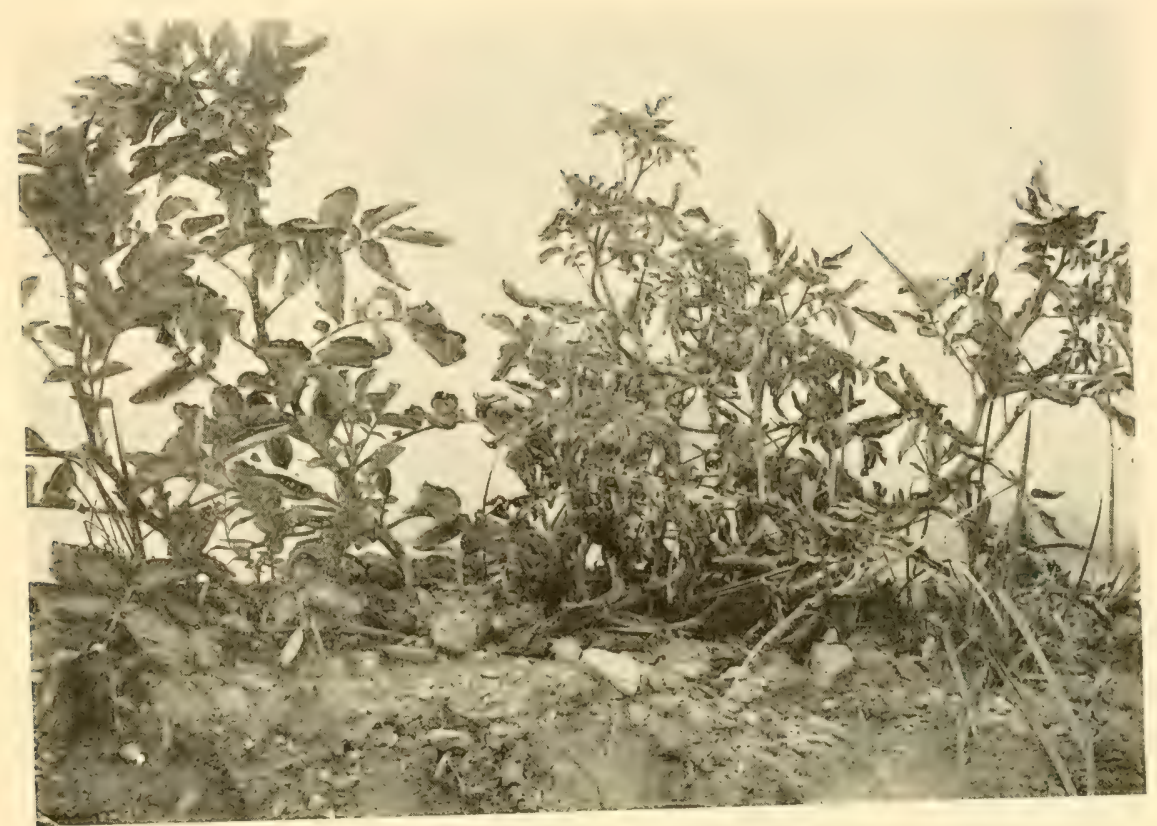

Fig. A

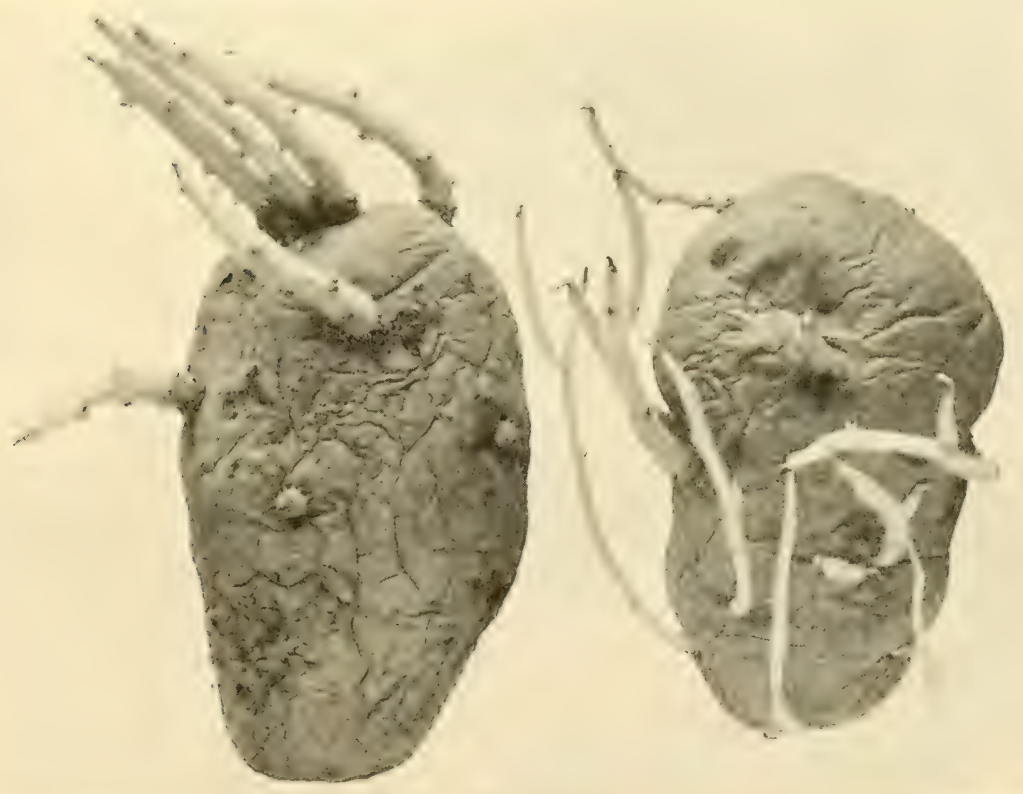

Fig, B

Haskell: Potato Fusarium Wilt 


\section{PLATE XIV}

FIG. A. A diseased plant of the Rural New Yorker type growing beside a comparatively healthy one of the same variety. The color of the stems of "bluesprouts" is usually darker and more intense in wilted plants than in healthy.

FIG. B. Green Mountain plant, practically dead from Fusarium wilt, that was carefully removed from the soil by washing. The photograph shows the effect of the disease on the root system and on the yield.

FIG. C. Aerial tubers produced on stems of affected Green Mountain potato plants. This phenomenon frequently occurs after the underground portion of the plant has become badly diseased:

FIG. D. The type of internal browning generally attributed to Fusarium oxysporum. Samples from Monroe County. This form of disease is sometimes found in the Hudson Valley but the browning does not usually extend inward so deeply as in this case and appears more like the condition shown in plate $\mathrm{XV}$. 


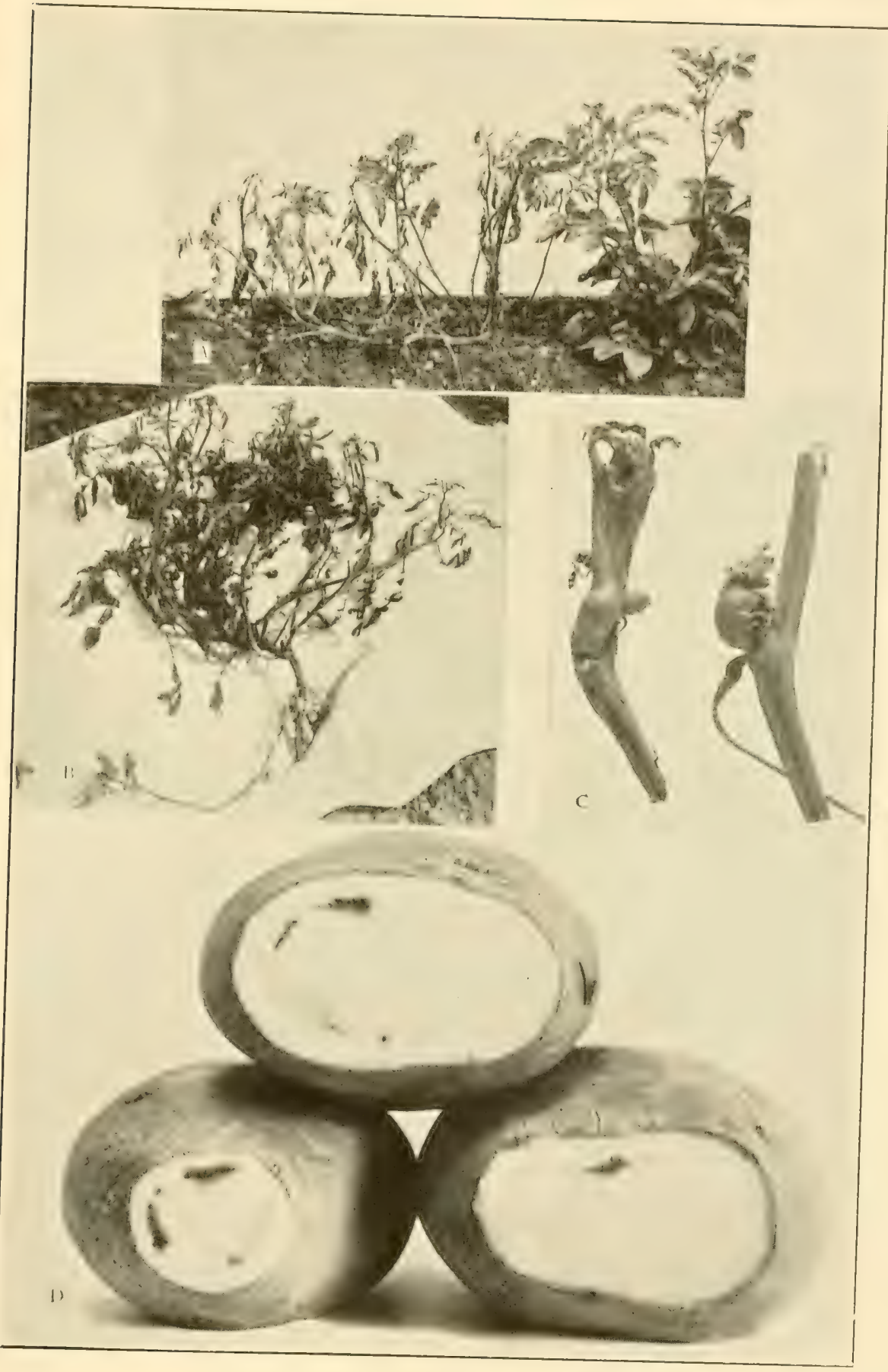

Haskeli: Potato Fusarium Wilt 


\section{PLATE XV}

Fig. A. Successive slices across the basal end of a potato affected with Fusarium necrosis showing the depth to which the browning extends into the tuber.

FIg. B. Stem-end browning artificially produced by injecting a five per cent solution of oxalic acid into the stem below ground.

FIg. C. Two tubers affected with Fusarium necrosis as it usually appears in Dutchess County.

FIG. D. Old potato tubers from a lot, seventy-five per cent of which were affected with Fusarium necrosis, showing progressive stages in the development of a rot about the point of attachment of the rhizome. 


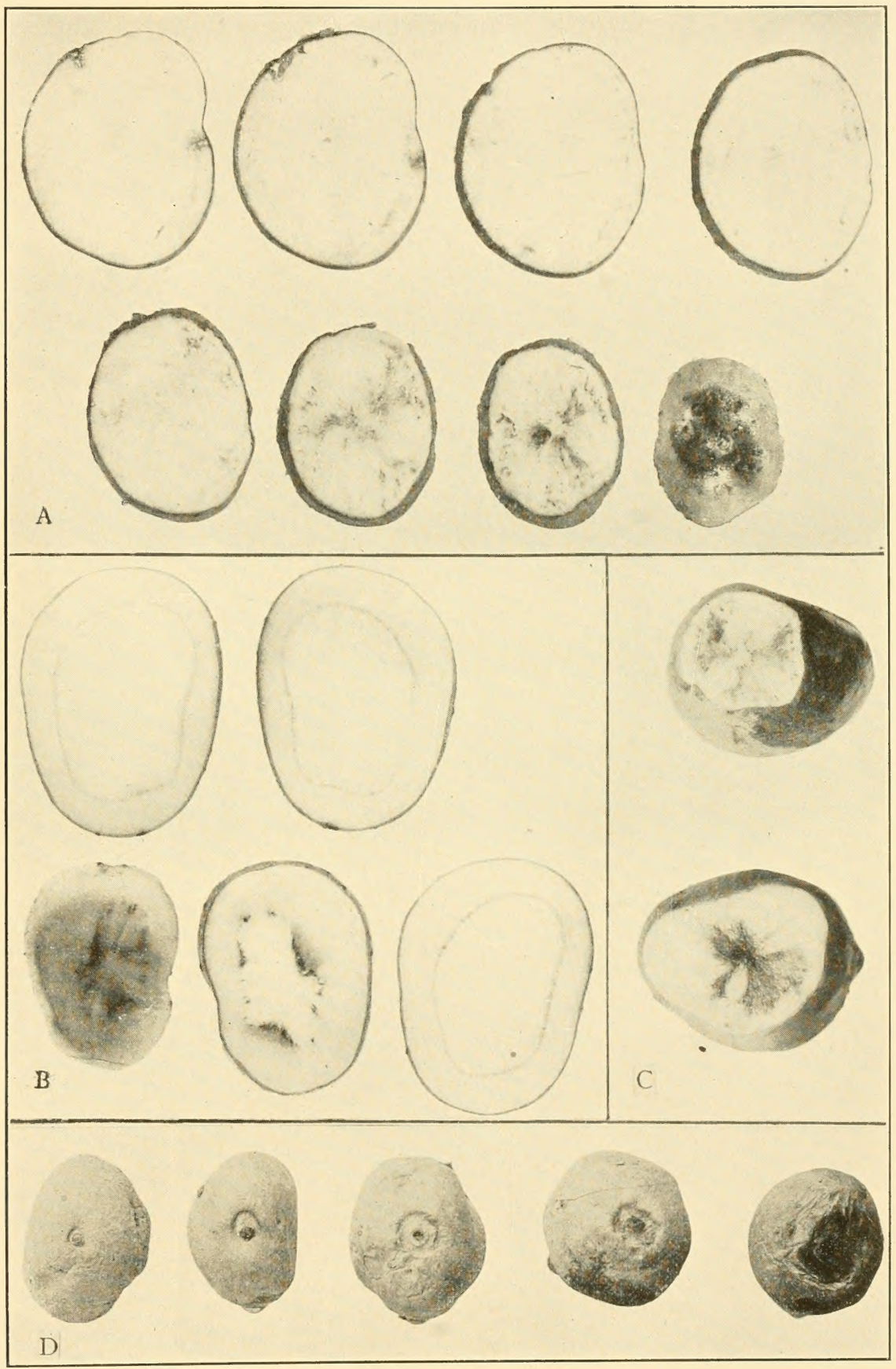

Haskell: Potato Fusarium Wilt 




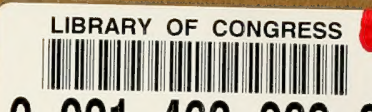

00214682898

. 